NBER WORKING PAPER SERIES

\title{
DEFERRED TAX POSITIONS AND INCENTIVES FOR CORPORATE BEHAVIOR AROUND CORPORATE TAX CHANGES
}

\author{
James Poterba \\ Nirupama Rao \\ Jeri Seidman \\ Working Paper 12923 \\ http://www.nber.org/papers/w12923
NATIONAL BUREAU OF ECONOMIC RESEARCH
1050 Massachusetts Avenue
Cambridge, MA 02138
February 2007

We are grateful to many research assistants at MIT and the University of North Carolina for collecting $10-\mathrm{K}$ data entries, to Erin Towery for outstanding research assistance standardizing the mountains of data, to William Gentry (the editor), James Hines, Richard Larsen, Thomas Neubig, Richard Sansing, Andrew Schmidt, Jake Thomas, two anonymous referees, and especially Lillian Mills for helpful comments and discussion, and to the American Tax Policy Institute, the Bradley Foundation, and the National Science Foundation for research support. The views expressed herein are those of the author(s) and do not necessarily reflect the views of the National Bureau of Economic Research.

(C) 2007 by James Poterba, Nirupama Rao, and Jeri Seidman. All rights reserved. Short sections of text, not to exceed two paragraphs, may be quoted without explicit permission provided that full credit, including (C) notice, is given to the source. 
Deferred Tax Positions and Incentives for Corporate Behavior Around Corporate Tax Changes James Poterba, Nirupama Rao, and Jeri Seidman

NBER Working Paper No. 12923

February 2007, Revised December 2010

JEL No. H25,M41

\begin{abstract}
$\underline{\text { ABSTRACT }}$
A firm's deferred tax position can influence how it is affected by a transition from one tax regime to another. We compile disaggregated deferred tax position data for a sample of large U.S. firms between 1993 and 2004 to explore how these positions might affect firm behavior before and after a pre-announced change in the statutory corporate tax rate. Our results suggest that the heterogeneous deferred tax positions of large U.S. corporations create substantial variation in the short-run effect of tax rate changes on reported earnings. Recognizing these divergent incentives is important for understanding the political economy of corporate tax reform.
\end{abstract}

James Poterba

NBER

1050 Massachusetts Ave

Cambridge, MA 02138

poterba@mit.edu

Nirupama Rao

Department of Economics

MIT

50 Memorial Drive

Cambridge, MA 02142-1347

nirupama@MIT.EDU
Jeri Seidman

The University of Texas at Austin

Austin, TX 78712-0211

jeri.seidman@mccombs.utexas.edu 


\section{INTRODUCTION}

Conventional wisdom holds that corporate executives support lower statutory corporate tax rates because after-tax corporate earnings would be higher if tax rates were lower. While this statement is an accurate long-run characterization for most firms, the short-run effects of a corporate tax rate reduction can differ widely across firms. These disparities, the result of differences in the tax circumstances of different firms, can potentially affect a firm's support for rate reduction.

When Congress debated corporate tax reform in 2004, survey evidence suggested that executives at a majority of firms supported rate reduction and preferred it to other tax reform options. Yet some large firms with substantial deferred tax assets that would have been revalued if the statutory corporate rate were cut lobbied successfully against such a cut. Hanna (2010) reports:

A corporate tax rate cut would cause a small group of manufacturing companies, on behalf of which the representatives were lobbying, to take an immediate charge or "hit" to earnings - thereby reporting lower quarterly net income and lower earnings per share (EPS). So even though a rate cut would benefit these manufacturing companies in future years, a current charge to earnings was unacceptable...

In part as a result of this lobbying effort, the American Jobs Creation Act of 2004 (AJCA) included a complex domestic activities production deduction that had the approximate effect of a rate cut but that did not reduce the statutory tax rate and therefore did not require write down their deferred assets and liabilities. This episode illustrates how deferred tax positions, and the incentives they create for some firms, can play an important role in the analysis of corporate tax transitions. $^{1}$

\footnotetext{
${ }^{1}$ Variation in firm circumstances with respect to deferred tax assets and liabilities are just one factor that might lead to variation across firms in support for a corporate rate reduction. A firm that had just completed an extensive investment program and expensed many of its investment costs, but was about to begin receiving the earnings from
} 
Several recent studies, including Shackelford, Slemrod, and Sallee (2009) and Edgerton (2010), examine whether managers focus attention on accounting earnings as well as cash flow. Robinson (2010) studies the market for low income housing tax credits and finds that, holding the tax benefit of the credit constant, firms will incur additional costs to obtain preferred accounting treatment. Managers appear willing to forego cash flow to raise pretax book income.

This paper aims to better understand the potential effect of deferred tax positions on corporate behavior and the way these positions may affect managerial preferences regarding corporate tax reform. Deferred tax asset or liability positions recognize the estimated future tax effects attributable to one type of difference between book and tax income, past temporary differences. The difference between reported pretax income and estimated taxable income is comprised of temporary, permanent and other differences. Temporary differences result from discrepancies in the timing of income and expense recognition for book and tax purposes. They affect a firm's cash flow for taxes both when they arise and when they reverse. The anticipation of this future reversal gives rise to the recorded deferred tax position. How a corporate tax reform will affect a firm's reported earnings in the year of its enactment, and how the firm may choose to react to the tax reform, depend in part on the sign and magnitude of its net deferred tax position. We collect data on the amounts and components of deferred tax assets and liabilities for the largest public U.S. corporations between 1993 and 2004. Our sample firms account for nearly forty percent of the aggregate market capitalization of the U.S. corporate sector in 2004.

The presence of deferred tax assets and liabilities not only matters for understanding the transitional impact of statutory tax rate changes on different firms, but also complicates the task

these investments, might be particularly supportive of a rate reduction. A firm that had undertaken similar investments but had been unable to fully expense the investments, because of tax loss carryforwards, would be relatively less supportive since the value of its carryforward claims would be reduced, along with the tax liabilities on its future earnings, by such a change. 
of estimating the revenue impact of a corporate tax change. Deferred tax positions generate additional incentives for firms to re-time their recognition of income around tax changes; this may in turn affect tax revenue. When tax rates are scheduled to decline, firms with large deferred tax assets have an incentive to accelerate the recognition of income to utilize deferred tax benefits at the currently high tax rate. For firms that have neither deferred tax assets or liabilities, and that are currently taxable, the prediction is reversed. These firms have an incentive to defer income until the low-tax regime takes effect. ${ }^{2}$ For firms with large deferred tax liabilities, the incentive is in the same direction as for currently taxable firms, but even stronger. These firms have an incentive to defer income to the anticipated low-tax regime since by doing so they can discharge their deferred liabilities at the lower statutory tax rate.

Scholes, Wilson, and Wolfson (1992) and Guenther (1994) study the Tax Reform Act of 1986 (TRA86), which reduced statutory corporate tax rates, and find that many taxable firms delayed reporting of income to take advantage of the new, lower tax rate. Maydew (1997) finds that firms generating Net Operating Losses in the years immediately following TRA86 delayed income recognition or accelerated deduction recognition to increase their losses, thereby moving the refunds from the carryback into a tax year with a high statutory rate. These results suggest that firms engage in shifting income across time periods when there are pre-announced changes in statutory corporate tax rates, and that the nature of these shifts depends on the firm's particular tax position.

\footnotetext{
${ }^{2}$ To shift taxable income, firms must often shift cash flow and occasionally book income as well. For example, firms may increase taxable income by accelerating the recognition of revenue, by accelerating the receipt of prepayments, or by slowing payment of non-recurring expenses; the first method impacts book income while the latter two affect cash flow. Financial reporting incentives - either to report higher income now, to smooth income over time, or to report lower income in order to preserve cushion for the future-may conflict with or exacerbate incentives to minimize tax liabilities. For example, the incentive to report higher current revenue for financial purposes conflicts with the standard tax-minimizing incentive to delay recognition of taxable income around a tax rate reduction.
} 
When tax rates or other relevant features of the tax code change, firms must revalue their deferred tax positions. This revaluation flows through current period accounting earnings (Net Income). As the size of U.S. corporations' deferred tax positions increases, the potential for revaluation of these balances to materially affect Net Income. While we focus on the impact of corporate tax changes, another recent example-the passage of the Patient Protection and Affordable Care Act of 2010-illustrates the potential importance of these changes. Leone (2010) explains that this legislation removed a tax benefit firms received by providing retiree drug benefits and required restatements of deferred tax assets related to the benefit that has been removed. For AT\&T Inc, this restatement decreased book income by $\$ 1$ billion and caused analysts, such as Credit Suisse, to issue guidance for investors on how to interpret this noncash charge. These anecdotes provide support for the suggestion by Mills (2006) and Neubig (2006), among others, that concerns about how potential legislation bearing on taxes and other issues will change reported income as a result of revaluations may be an important determinant of whether corporate executives support such proposals.

This study explores the potential influence of deferred tax positions on the way firms respond to tax changes and on the incentives managers may face when they lobby with regard to tax policy. While we do not examine the political actions of firms, we suggest that a political economy perspective on firm behavior might offer useful insights on corporate support for, and opposition to, various corporate tax reforms. ${ }^{3}$ We construct and describe components of assets and liabilities for large corporations. We identify all public firms that are in the Fortune 50 between 1995 and 2004 and carefully construct comparable entities for the period 1993 to 2004

\footnotetext{
${ }^{3}$ We focus on temporary differences, rather than permanent differences, because permanent differences do not accumulate over time in the form of deferred tax assets or liabilities. They do not create incentives with regard to tax policy transitions in the way that temporary differences do. The full impact of a permanent difference is recognized in the period when the underlying income-generating activity takes place.
} 
by combining merged companies prior to the merger and divested companies after the divestiture. For this set of 81 "super-firms," we then catalog the components of their deferred tax positions so we can investigate changes within category and in total for each firm.

Hand-collection is necessary because the available machine-readable balance sheet data has historically encoded only the long-term deferred tax liability disclosed on the balance sheet, rather than the net deferred tax position and the components disclosed in the tax footnote. While the most recent Compustat data format includes net deferred tax positions, the process of backfilling prior years that were not originally collected is not yet complete. This data field is populated in the Compustat data file for only 50.9 percent of the firm-years in our sample. The machine-readable data file therefore does not permit analysis of short-term deferred tax liabilities or any deferred tax assets. This makes it impossible for researchers to measure the magnitude of deferred tax assets that are likely to influence the amount of lobbying for or against prospective tax rate changes, or the extent of income shifting that might take place as firms try to utilize NOLs when faced with a statutory tax rate reduction.

The aim of our study is to calculate the size of net deferred tax asset and liability positions in order to allow policy-makers to better understand the potential revaluation effects facing large U.S. corporations. We also provide evidence on how changes in temporary differences - both aggregate temporary differences and specific types of such differences-are linked with the recent rise in the difference between reported pretax book income and estimated taxable income (the book-tax gap).

Our analysis has three parts. First, we measure both the total book-tax gap and the portion of the gap attributable to temporary differences. Our hand-collected firm-level data set enables us 
to overcome missing-data problems that are common in the standard data source, Compustat. ${ }^{4}$

Our findings suggest that temporary differences account for a substantial share of the book-tax gap. When we stratify our data by year, we find that in every year, more than half of the book-tax gap for the median firm in our sample is attributable to temporary differences. ${ }^{5}$ Additionally, both the fraction of firms in our sample with a net deferred tax liability and the size of the average net deferred tax liability rise substantially during our sample. Thus, growth in temporary differences appears to contribute to the widening of the book-tax gap. As a firm's deferred tax position rises relative to its non-tax assets and liabilities, the firm is likely to be more sensitive to proposed changes in statutory corporate tax rates.

Second, we disaggregate deferred tax positions into categories in order to understand whether the recent growth in the book-tax gap attributable to temporary differences is observed over most of the components that contribute to temporary differences, or is driven by a few specific types of temporary differences. This disaggregation provides the first detailed analysis of the components of deferred tax positions for a significant and relatively constant sample of firms over an extended period of time. ${ }^{6}$ Key contributors to the increase in the book-tax income gap include mark-to-market adjustments; property, including leases and both tangible and intangible property; and valuation allowances.

\footnotetext{
${ }^{4}$ We use current tax expense to calculate the book-tax income gap and deferred tax expense to calculate temporary differences. In our hand-collected data set, current tax expense (deferred tax expense) is non-missing and non-zero for 92.4 percent ( 91.2 percent) of our firm-year observations. Compustat current tax expense, calculated as the sum of federal, foreign, and state current tax expense - Compustat codes TXFED, TXFO and TXS, respectively - is nonmissing and non-zero for 74.8 percent of the firm-years in our sample; Compustat deferred tax expense, calculated as the sum of federal, foreign, and state deferred tax expense-Compustat codes TXDFED, TXDFO and TXDS, respectively-is non-missing and non-zero for 62.6 percent of the firm-years in our sample.

${ }^{5}$ The residual (Book Income less [(Current plus Deferred Tax Expense)/0.35]) should be attributed to permanent and other differences as well as to measurement error. Tax expense not clearly disclosed as current or deferred (for example, tax expense due to Discontinued Operations or disclosed only by jurisdiction) will be included in this residual measure.

${ }^{6}$ Amir, Kirschenheiter, and Willard (1997) collect similar data on the size and components of deferred tax positions but only study the period 1992-1994. Phillips, Pincus, Rego, and Wan (2004) study a longer period, 1994-2000, but study a random sample of firm-years in this period. We collect data for a relatively constant set of firms over a long period, which allows us to make across-time comparisons.
} 
Finally, we interpret the data we collect on deferred tax assets and liabilities in the context of the behavioral and political economy incentives surrounding a tax rate change. We find that a pre-announced reduction in the corporate tax rate would give a third of the firms in our sample a strong incentive to accelerate income to the high-tax period. Moreover, many of these firms have taxable income in the current period, which suggests that they are likely to have the capacity to make such a shift. While we are unable to estimate how much income would be shifted in response to such incentives, and the incentive to make such a shift would depend on the size of the rate change, the nontrivial share of firms with such an incentive and the rising value of loss carryfowards, suggests that analysts should consider the revenue impact of ratechange-motivated income shifting when they estimate the short-run revenue effect of a change in the statutory corporate tax rate.

We also estimate the impact of a change in the statutory corporate tax rate on Net Income to demonstrate how such a change might influence the incentives firms have to lobby for or against pending tax legislation. For the average firm in our sample, reducing the statutory federal corporate income tax rate from 35 to 30 percent would result in a $\$ 328$ million increase in reported Net Income as a result of revaluation of deferred tax positions. There is, however, substantial heterogeneity across firms. More sample firms would report an increase than a decrease in Net Income from revaluations associated with a reduction in the statutory corporate tax rate. Among those that would report an increase, the average impact of a rate reduction to 30 percent would be $\$ 677$ million. For firms with a net deferred tax asset, however, the rate reduction would induce an average reduction of $\$ 315$ million in Net Income. Our results quantify a potentially important transitional effect of corporate tax reform on Net Income-the revaluation effect of deferred tax positions - that policy-makers may want to consider as they try 
to target transition relief in prospective tax legislation to the various types of firms that may be affected by policy changes.

We divide our analysis of temporary book-tax differences into five sections. The next section-section two- explains how temporary differences generate deferred tax assets and liabilities. This background is particularly important for non-accountants. Section three describes the data set that we have assembled from a sample of SEC filings, identifies a number of potential data limitations and presents summary statistics. Section four disaggregates the booktax gap, both to estimate the importance of temporary differences within our sample and to provide details on the most significant components of temporary differences. Section five examines how the sum of past temporary differences can affect book income when tax policy changes induce revaluations. A brief conclusion explores implications of our findings for tax policy and suggests future research.

\section{TEMPORARY DIFFERENCES BETWEEN BOOK AND TAX EARNINGS}

Statement of Financial Accounting Standards 109 (SFAS 109) provides guidance for the calculation of tax expense. Following the "matching principle," a central concept of accrual-basis accounting which states that expenses should be matched to the period in which they give rise to revenue rather than to the period in which they arise or are paid, SFAS 109 stipulates that the total tax expense reported in a period should be the estimate of total income taxes due on the pretax book earnings of that period. Generally, accounting earnings reported to investors in a 10$\mathrm{K}$ differ from taxable income reported to the Internal Revenue Service (IRS) on Form 1120, so the total tax expense reported in the $10-\mathrm{K}$ will not equal taxes currently due to the IRS.

While book income and taxable income may differ for a number of reasons, they can be separated into two broad categories: permanent differences and temporary differences. 
Permanent differences arise when a component of income enters one earnings measure but is never included in the other. For example, all forms of interest income are included in pretax book income but interest on tax-exempt state government bonds is excluded from taxable income. This exclusion is an example of a permanent difference. In contrast, temporary book-tax differences are the result of disparities in the timing of when an income component is included in book and taxable income. For example, bad debts are estimated and expensed for book purposes in the period in which the associated revenue is recognized, but bad debts are not deducted for tax purposes until specific receivables are written off.

SFAS 109 requires the calculation of two components of total tax expense, current tax expense and deferred tax expense. Current tax expense measures income taxes due in the current taxable year, while deferred tax expense measures income taxes due in all future taxable years. Total tax expense equals the sum of current and deferred tax expense. Permanent differences primarily affect the calculation of total tax expense by adding to or removing from book income items that will never be a component of taxable income, such as interest on state government bonds, non-deductible fines, and the domestic manufacturing deduction. This implies that total tax expense equals the statutory corporate tax rate times taxable book income less tax credits and other rate adjustments. Taxable book income equals pretax book income less permanent differences. ${ }^{7}$

If a company had permanent differences but no temporary differences, then it would have no deferred tax expense. Its total tax expense would equal its current tax expense. When a company has temporary differences, a portion of its total income tax expense that would be

\footnotetext{
${ }^{7}$ We refer to tax credits and other rate adjustments that affect current tax expense reported in the financial statements but not taxable income reported on Form 1120 as "other differences". These other differences confound our measure of taxable income because we are forced to estimate taxable income from 10-K-reported current tax expense.
} 
currently due to the IRS based on current period taxable book income is deferred. Temporary differences essentially reclassify a portion of tax expense from current tax expense to deferred tax expense. For example, consider a firm with $\$ 100$ of accelerated tax depreciation in excess of straight-line book depreciation. Its current-period taxable income will be $\$ 100$ lower than it would have been absent this deduction. As a result of this temporary difference, a tax expense of $\$ 100 * \tau$ that would have otherwise been due on current taxable book income will be due in some future tax period. In one or more future years, the firm's straight-line book depreciation will exceed its tax depreciation, taxable income will exceed book income, and the $\$ 100^{*} \tau$ of previously-deferred tax expense will become due. When the full amount of the deferred tax related to a temporary difference has been paid or received, the temporary difference is said to have 'reversed'.

Because temporary differences create a reclassification of tax expense between current tax expense and deferred tax expense, they do not affect the total dollars of tax that will be paid over the life of the firm or the total tax expense that is recorded in the company's financial statements. Temporary differences only affect the timing of tax payments. Each temporary difference affects the calculation of taxable income and tax due to the IRS in at least two yearsonce in the year when it arises, and again in the year or years in which it reverses. In the foregoing depreciation example, the $\$ 100$ of accelerated tax depreciation in excess of book depreciation created a current-year book-tax difference, as well as a future, opposite-signed book-tax difference when it reverses. While temporary differences affect both taxable income and cash flow for taxes in at least two years, in the absence of revaluation due to changes in tax rates or laws, temporary differences do not affect total tax expense or book income. 
Because temporary differences represent a future obligation to pay cash to or receive tax relief from the IRS, they must be accounted for as financial assets or liabilities. Deferred tax asset and liability positions accomplish this; deferred tax positions equal the current statutory corporate tax rate times the sum of differences that will reverse in the future. Firms for which pretax book income has exceeded taxable income have a net deferred tax liability (DTL): these firms have an accumulation of 'favorable' temporary differences that have allowed them to defer tax expense to a future period and this deferral has created a liability to the government. Firms for which taxable income has exceeded pretax book income, in contrast, have a deferred tax asset (DTA); they have an accumulation of 'unfavorable' temporary differences that have forced them to accelerate tax payments and they are therefore entitled to future tax relief.

A firm's end-of-period deferred tax position is equal to cumulated temporary differences times the statutory corporate tax rate expected to be in effect, under currently enacted laws, when the temporary differences reverse. ${ }^{8}$ When expected tax rates are constant through time, a firm's deferred tax expense equals the current statutory tax rate times temporary book-tax differences that arise or reverse in the current period. ${ }^{9}$ When tax rates change, SFAS 109 requires firms to revalue net deferred tax positions and to include these revaluations in book income through the deferred tax expense or benefit. ${ }^{10}$

To illustrate the revaluation principle, consider a firm with one relatively new asset subject to accelerated tax depreciation relative to book depreciation and no other temporary

\footnotetext{
${ }^{8}$ Under SFAS 109, temporary differences are recorded without discounting to reflect the elapsed time until reversal.

${ }^{9}$ This is a simplification of the balance sheet approach of SFAS 109 for expositional purposes. It does not hold when the statutory rate changes, merger activity occurs, or in certain other settings. SFAS 109 actually requires the deferred tax expense to be calculated as the change in the firm's net deferred tax position, rather than as the current period's temporary differences times the statutory rate.

${ }^{10}$ Revaluation of the deferred tax balance flows through Net Income regardless of whether or not the creation of the deferred tax balance affected net income. For example, deferred tax expenses associated with unrealized gains and losses on available for sale securities affect Other Comprehensive Income rather than Net Income but revaluation of these positions would nonetheless affect Net Income.
} 
differences. In the year when it acquires this asset, the firm records a deferred tax expense and liability related to this asset in the amount of $\tau^{*}\left(\right.$ depreciation $_{1, \text { book }}$-depreciation $\left.{ }_{1, \text { tax }}\right)$, where the subscript denotes the age of the asset (with 1 denoting the year of its purchase) and the type of depreciation, tax or book. This expression indicates that at some point in the future the accelerated tax depreciation deduction will be less than the book depreciation expense and then the IRS will expect to receive additional tax at the rate of $\tau$. Similarly, in the next year, the deferred tax liability related to this asset will increase by $\tau^{*}\left(\right.$ depreciation $_{2, \text { book }}$-depreciation $\left.n_{2, \operatorname{tax}}\right)$. The firm now has a deferred tax liability due to the IRS of $\Sigma_{\mathrm{j}=1,2} \tau^{*}\left(\right.$ depreciation $_{\mathrm{j}, \text { book}^{-}}$ depreciation $_{\mathrm{j}, \text { tax }}$ ). When $\tau$ changes to $\tau^{\prime}$, not only does the layer added by this year's difference between book and tax depreciation change, but also the balances previously recorded change because the IRS will now expect to settle this liability at $\tau^{\prime}$, rather than at $\tau$. The new liability recorded on the balance sheet will equal $\Sigma_{\mathrm{j}=1,2} \tau^{\prime} *\left(\right.$ depreciation $_{\mathrm{j}, \text { book }}$-depreciation $\left.\mathrm{j}_{\mathrm{j}, \text { tax }}\right)$. Assuming that the deferred tax expense for year 2 was recorded at the historic rate $\tau$, an adjustment equal to $\Sigma_{\mathrm{j}=1,2}\left(\tau-\tau^{\prime}\right)^{*}\left(\right.$ depreciation $_{\mathrm{j}, \text { book }}$-depreciation $\left.\mathrm{j}_{\mathrm{j}, \text { tax }}\right)$ will be reported in book income. In this example of a net deferred tax liability position, a tax rate decrease will cause the liability to decrease and Net Income to increase. If the firm had a net deferred tax asset position, the effect of a rate change would be reversed.

We study temporary differences by analyzing reported deferred tax positions. Three features of SFAS 109 that affect these reports are particularly significant for our study. First, firms must report both deferred tax assets and liabilities, not just a net deferred tax position. Deferred tax positions are categorized as current or non-current based on the underlying asset or liability that gave rise to that position. Deferred tax positions are aggregated based on this classification and both a net current deferred tax asset or liability and a net non-current deferred 
tax asset or liability is presented on the balance sheet. Second, firms must adjust their reported DTAs and DTLs when laws change, in particular to reflect changes in statutory corporate tax rates. For many firms, and for many but not all components of deferred taxes, a reduction in the statutory corporate tax rate would reduce DTLs (DTAs) and thereby have a positive (negative) effect on reported earnings. Third, firms must report a valuation allowance that reflects the probability of realizing deferred tax assets. ${ }^{11}$ This permits an assessment of the potential tax benefit associated with a deferred tax asset.

Disaggregating deferred tax assets and liabilities makes it possible to study many aspects of deferred tax positions, but we are aware of only four studies that have moved beyond machine-readable data to examine the components of the deferred tax account. ${ }^{12}$ Phillips, Pincus, Rego, and Wan (2004) explore which types of deferred tax positions reveal aggressive financial reporting. They find that changes in deferred tax positions related to revenue and expense accruals and reserves are particularly likely to signal aggressive financial reporting. Givoly and Hayn (1992) study how share prices of firms with deferred tax liabilities reacted to the corporate tax rate reduction in the 1986 Tax Reform Act. They find that the decline in corporate rates had a favorable effect on the market value of firms with deferred tax liabilities, after controlling for the other effects of tax reform. Chen and Schoderbek (2000) distinguish changes in deferred tax positions that were triggered by the 1993 corporate tax rate increase from other changes to deferred tax positions. They find that analysts reacted in roughly the same way to both types of changes, even though the persistence and predictive power of the two are likely to differ. Finally,

\footnotetext{
${ }^{11}$ A valuation allowance is a contra-asset account that reflects the value of deferred tax assets that are not likely to be recognized. (A contra-asset is an account that is entered on the asset side of the balance sheet even though it has a credit balance. This is done to reflect that the credit - negative - balance in the contra-asset offsets some debitpositive - balance in the associated asset account. The valuation allowance contra-asset decreases the value of the deferred tax asset.) The deferred tax asset is netted with the valuation allowance to assess the firm's expected future tax benefit.

${ }^{12}$ Several studies analyze a portion of the deferred taxes. For example, Miller and Skinner (1998) and Bauman, Bauman, and Halsey (2001) study the valuation allowance related to deferred tax assets.
} 
Amir, Kirschenheiter, and Willard (1997) find some evidence that market participants consider the source of deferred tax positions in valuation. We follow these studies in disaggregating deferred tax balances, but we focus on how temporary differences change over time and on how they affect the income statement rather than market values.

\section{DATA COLLECTION}

Machine-readable data, such as the deferred tax liability balance recorded by Compustat, measure firms' deferred tax positions with substantial noise. Until recently, Compustat collected deferred tax liabilities that were separately stated on the face of the balance sheet, but it omitted deferred tax positions reported as assets or included in other liabilities, thereby preventing researchers from identifying firms with net deferred tax assets or from accurately measuring the position of firms with net liabilities. ${ }^{13}$ Compustat's new database format (termed 'Fundamentals'), introduced in 2007, collects data on net deferred tax positions as well as the balance of short-term and long-term deferred tax assets and liabilities. ${ }^{14}$ This dramatically improves the ability of researchers to measure net deferred tax positions. However, the Fundamentals dataset does not yet contain data for all firms for all years. ${ }^{15}$ Our dataset has many advantages over the historical Compustat format (termed 'Legacy'). Relative to Fundamentals Compustat, its primary advantage is its completeness.

\footnotetext{
${ }^{13}$ For example, the 2005 balance sheet for Kimberly-Clark reports a current deferred tax asset of \$223.4 million and a long-term deferred tax liability of $\$ 572.9$ million. Legacy Compustat only collects the liability disclosed on the balance sheet of $\$ 572.9$ million. Even if Compustat had also collected the balance-sheet-disclosed current asset of \$223.4 million, the user would not have been able to tie to the footnote-disclosed net deferred tax liability position of $\$ 121.4$ million because of deferred tax positions included in other assets on the balance sheet.

${ }^{14}$ In the 2005 Kimberly-Clark example of the previous note, Fundamentals Compustat collects $\$ 223.4$ million for short-term deferred tax assets, \$228.1 million for non-current deferred tax assets, and \$572.9 million for long-term deferred tax liability as well as the net deferred tax liability position of (\$121.4) million.

${ }^{15}$ Fundamentals Compustat has backfilled tax data for a number of firms and continues to backfill fairly rapidly (nearly 30 percent of our sample was populated during the first six months of 2010.) However, only 50.9 percent of the valid observations during our period have a non-missing value for Net Deferred Tax Balance. We found that 96.9 percent of the Net Deferred Tax Balances collected by Compustat are approximately equal to the Net Deferred Tax Balances we hand-collected.
} 
A second limitation of machine-readable data is that it does not allow detailed component-based analysis of deferred tax asset and liability positions. As part of our study, we endeavor to provide evidence about which types of differences have contributed to the rise in the book-tax gap. Neither Fundamentals Compustat nor Legacy Compustat includes information on the type of temporary difference which created the deferred tax position.

We collect data from the tax footnote in 10-K filings for FORTUNE 50 firms for fiscal years between 1993 and 2004. Our sample begins in FY 1993 because it is the first year when all firms' financial statements were prepared in accordance with SFAS 109, which took effect for fiscal years beginning after December 15, 1992. FORTUNE ranks firms by gross revenue. ${ }^{16}$ Our sample includes both financial and non-financial firms. Since we are interested in tracking deferred tax positions over time, we use the annual FORTUNE 50 lists to construct a panel data set. For any firm in the FORTUNE 50 in any of our sample years, we collect data for the entire sample period. There is moderate turnover in the FORTUNE 50 . Only 25 of the firms in the 1995 FORTUNE 50 were in the 2004 FORTUNE 50. Nine of the 50 firms on the 1995 list were acquired between 1995 and 2004. In a typical year, five firms leave the FORTUNE 50 for various reasons. One hundred firms appear in the FORTUNE 50 at least once between 1995 and 2004. We drop four firms from this group: State Farm Insurance and TIAA-CREF, private companies that are not required to file $10-\mathrm{Ks}$, and Fannie Mae and Freddie Mac, which are government-sponsored enterprises. This leaves a sample of ninety-six firms.

Corporate control transactions complicate the problem of tracking FORTUNE 50 firms through time. Sample firms acquire other firms, or in some cases are themselves acquired. When this occurs we collect data on the acquired or acquiring firm for years prior to the acquisition. To

\footnotetext{
${ }^{16}$ Prior to 1995 , FORTUNE rankings included only manufacturing firms. To avoid including firms that are only in the FORTUNE 50 due to the exclusion of non-manufacturing firms, we formed our sample using the FORTUNE rankings from 1995-2004.
} 
preserve data comparability over time, we create "super-firms" by combining the distinct accounts of the two firms that subsequently consolidated. This process is designed to minimize discrete changes in deferred tax positions that are due to acquisitions. However, no methodology we know of will completely eliminate these changes because the merger itself can create deferred tax assets and liabilities. ${ }^{17}$

Because most of the companies acquired by FORTUNE 50 firms are companies that are not part of the FORTUNE 50, constructing super-firms involves data collection on many small companies. This increases the number of firms in our sample in at least one year to 420 ; these firms combine to create 81 super-firms. Due both to limited availability of electronic filings in the early years of our sample and to the non-traded nature of some firms, the number of superfirms in our sample rises from 71 in the first year (1993) to 78 in the final year (2004). Appendix A lists the individual firms in our sample. Our analysis relies on super-firms rather than individual companies as our units of observation to preserve comparability across years.

SFAS 109 mandates: (i) an income tax summary, which details the significant components of income tax expense; (ii) a rate reconciliation, which reconciles reported income tax expense with the amount that would result from applying the domestic federal statutory rate to pretax income; and (iii) a schedule of deferred tax positions, which provides information about DTAs and DTLs. Firms also are expected to disclose information regarding the amounts and expiration dates of loss and credit carry-forwards, the division of tax expense between continuing operations and all other items, the composition between domestic and foreign earnings before

\footnotetext{
${ }^{17}$ Our super-firm methodology will minimize differences due to non-taxable mergers accounted for as a pooling-ofinterest. However, a non-taxable merger accounted for as a purchase will result in stepped-up basis for book but not tax purposes, increasing deferred tax liability positions. While our methodology, computing the change between the merged firm and the sum of the target and the acquiring firm, will usually reduce the change relative to considering a change between the merged firm and the acquiring firm only, our methodology does not always eliminate the change caused by the merger.
} 
income taxes, and temporary differences for which the firm has not recorded a deferred tax liability, including permanently reinvested foreign earnings.

We match each firm-year observation with Compustat using both firm name and year, and validate the match using total assets and Net Income. ${ }^{18}$ We collect the tax summary, rate reconciliation, and the schedule of deferred tax positions from tax footnotes. There is substantial variation across firms in the level of detail presented in the tax footnote, although most firms follow a fairly stable reporting policy from year to year. Appendix B describes our procedure for disaggregating DTAs and DTLs into their component parts.

There are several data limitations inherent in our approach to collecting and disaggregating the components of deferred tax assets and liabilities. First, our procedure is limited by the level of disclosure provided in the 10-K. Firms who disclose relatively few line items or use vague language hamper our categorization efforts. Second, SFAS 109 is a worldwide consolidated firm disclosure. Most firms are taxed in multiple jurisdictions, but they do not make jurisdiction-specific income tax disclosures. Rather than allocating DTAs and DTLs across jurisdictions in an arbitrary fashion, we assume that all DTAs and DTLs relate to federal temporary differences. Finally, there may be heterogeneity across firms in the auxiliary assumptions that are used to compute and present the value of DTAs and DTLs. We do not have any information regarding the detailed calculations underlying the tax footnotes, so we are unable to address such potential heterogeneity or its effects.

\section{SUMMARY FINDINGS}

\footnotetext{
${ }^{18}$ We collected tax information from the first $10-\mathrm{K}$ or annual report filing for each fiscal year. Restatements may cause differences between the total assets and net income entries in the 10-K and those reported in Compustat. We hand-checked the 48 firm-years where neither Compustat codes AT nor NI corresponded to our hand-collected total assets and net income numbers. The majority of differences were due to small restatements. We dropped 17 firmyears, 15 for which Compustat did not have any data and two where a stub year or merger caused a mismatch.
} 
We begin our analysis by reporting summary statistics. Table 1 reports aggregate and median values of the estimated book-tax income gap, temporary differences, and the share of the book-tax income gap attributable to temporary differences for our super-firm sample. We define the book-tax income gap on a world-wide basis as Pretax Income less estimated Taxable Income, where Taxable Income is defined as Current Tax Expense divided by the maximum U.S. corporate statutory tax rate (35 percent throughout our sample). We calculate temporary differences as Deferred Tax Expense divided by 0.35 . We present and discuss two alternative calculation approaches in Appendix C. The share measure equals the book-tax gap due to temporary differences divided by the total book-tax gap. While Compustat in principle collects the data necessary for both of these calculations, we find that Current Tax Expense in Compustat, which we calculate as the sum of TXFED, TXFO and TXS, is missing or zero for 25.2 percent of the firm-year observations. By comparison, Current Tax Expense is only missing or zero for 7.6 percent in the comparable set of firm-years in our hand-collected data. Deferred Tax Expense in Compustat, which we calculate as the sum of TXDFED, TXDFO and TXDS is missing or zero for 37.4 percent if the firm-year observations; it is missing or zero for 8.8 percent of the firm-year observations in the comparable component of our dataset. Given these discrepancies, we use hand-collected data for the calculations throughout the paper.

[insert Table 1 around here]

The third through fifth columns of Table 1 present medians. The median share attributable to temporary differences is the median of (estimated temporary differences/estimated total book-tax gap), calculated at the super-firm level. For the median firm in our sample, the share of the imputed book-tax difference attributable to temporary differences varies across years, ranging from 61.3 percent in 1994 to 93.2 percent in 1999. In every year, however, 
estimated temporary differences comprise the majority of the estimated book-tax gap for the median super-firm in our sample.

In columns six through eight of Table 1, we report aggregate statistics. The aggregate share attributable to temporary differences is calculated as the sum of temporary differences across super-firms divided by the sum of the book-tax gap across super-firms. This measure offers further insight into the distribution of temporary differences. For example, in 2001 the median super-firm reports a positive book-tax gap and positive temporary differences but the aggregate figures are both negative. Just slightly less than half of the sample firms, 43.6 percent, report a negative book-tax gap in 2001. On average, the negative values are significantly larger ( $\$ 2.942$ billion) than the positive values of the book-tax gap, which average $\$ 1.814$ billion. The difference between the median and the aggregate (or the mean) arises because firms with large book-tax gaps or large temporary differences are more influential in the computation of the aggregate measure than in the computation of the median. For instance, the very large aggregate share attributable to temporary differences in 2002 is driven by AOL Time Warner Inc., which reports a book-tax gap of (\$46.254 billion) but temporary differences of only ( $\$ 1.42$ billion). ${ }^{19}$ Even though the aggregate ratio is less stable than the median ratio, both measures yield a similar inference: temporary differences are the largest component of the book-tax gap for the firms in our sample.

Table 2 presents additional information on the total market value and assets for the firms in our sample. Market Value of Equity is calculated as Compustat Common Shares Outstanding (CSHO) multiplied by fiscal year-end price (PRCC_F); all other variables are hand-collected.

\footnotetext{
${ }^{19}$ There is not a lone culprit for the negative share attributable to temporary differences in 1998 but rather three super-firms that report large negative book-tax differences and either a small negative or a positive book-tax gap: Citigroup, IBM, and Johnson \& Johnson. Removing these three super-firms results in an aggregate book-tax gap of $\$ 9.588$ billion, 28.4 percent of which is attributable to temporary differences.
} 
With regard to market value of equity (assets), our sample represents 39.2 percent (41.9 percent) of the Compustat universe in 2004 and averages 41.2 percent (40.3 percent) over our whole sample period.

The last four columns in Table 2 show the number of firms in each sample-year that report net deferred tax assets, the number that report net deferred tax liabilities, and the total value of these net deferred tax positions. The data demonstrate the heterogeneity in firm tax positions, as well as the evolution of these positions through time. In 1993, 31 of 72 super-firms report net deferred tax assets that total $\$ 52.2$ billion, while the remaining 41 report net deferred tax liabilities totaling $\$ 79.7$ billion. The proportion of net DTL firms increases through our sample period, and in 2004, 27 of 78 super-firms report net DTAs. While Neubig (2006) cites a recent survey that suggests that the majority of surveyed firms prefer a lower corporate tax rate to other incremental or fundamental tax reforms, Table 2 suggests that there is a significant minority of firms that would experience at least one adverse effect of such a rate reduction-a decline in the value of their DTAs.

[insert Table 2 around here]

Table 2 suggests that the share of firms with net DTLs rose during our sample period. A net DTL, indicating cumulative book income higher than taxable income, could be due to a number of factors, including but not limited to aggressive financial reporting which raises pretax book income and aggressive tax reporting which lowers taxable income. In addition to showing an increase in the proportion of firms with a net DTL, the table also shows that firms with a net DTL have larger deferred tax positions than firms with a net DTA. In 1993, the average net DTL is $\$ 2.0$ billion while the average net DTA is $\$ 1.7$ billion. The average net DTL increases by 122 percent during our sample period, to $\$ 4.4$ billion in 2004 , while the average net DTA increases 
by only 42 percent. This is consistent with the increase in DTLs over our sample period that was evident in Table 1.

Tables 3 and 4 explore the increases in temporary differences that have contributed to the rise in the book-tax income gap and present detailed information on the composition of deferred tax positions. Table 3 disaggregates deferred tax positions into their constituent components, and indicates the sources of the most important temporary book-tax differences. Table 4 separates DTA positions from DTL positions for components that do not consist almost exclusively of either assets or liabilities. We report means of these disaggregate measures to facilitate comparison across years with different sample sizes.

\section{[insert Table 3 around here]}

The results in Table 3 suggest some variation over time in the key sources of deferred tax positions within our sample. The most important source of deferred tax liabilities is Property. Early in the sample, the most important source is Benefits, which includes benefits related to current employees as well as retiree health benefits and pensions. This is not a surprise, because our sample begins in 1993 shortly after SFAS 106, Accounting for Other Postretirement Benefits, required firms to record liabilities for unfunded retiree medical costs. In the following decade, many companies eliminated or scaled back such coverage, thereby decreasing the DTA values associated with Benefits. By the end of the sample in 2004, Credits and Carryforwards replaces Benefits as the most significant deferred tax asset, although Benefits remains a major contributor. Although the economy had substantially recovered by 2004, many firms likely still have unused loss and credit carryforwards from the economic downturn of 2001.

While the overall ranking of various components of deferred tax assets does not change dramatically between 1993 and 2004, the magnitude of certain categories does. For example, 
deferred tax positions related to mark-to-market adjustments rise and fall with the general equity market. NOL Carryforwards increase 248 percent while Other Tax Credits and Carryforwards increase 148 percent, consistent with the extension of the carryforward period under the Taxpayer Relief Act of 1997. Deferred tax liabilities related to Property, Plant and Equipment $(P P E)$ increase 45 percent. Possible explanations for the rise in PPE include special "bonus tax depreciation" that took effect in 2001 as well as the implementation of SFAS 142, which removed book amortization of intangible assets. Liabilities related to Intangible Assets and Leases rise 113 percent and 77 percent, respectively. Intangible Assets includes goodwill and is likely a result of substantial merger activity recently. Some fraction of the rise in leasing-related deferred tax components may reflect a rise in either, or both, of aggressive financial and tax reporting using leased assets. Table 3 also shows that book revenues rose relative to tax revenues during the 1990s, a result consistent with Plesko's (2004) study. The data in Table 3 suggests that the increase in temporary differences that contributed to the rise in the book-tax income gap was not driven by a single source, but was instead the result of increases in many deferred tax liabilities including Property, Subsidiary-Related Items and Valuation Allowance (the latter being a contra-asset).

In addition to describing which categories have contributed most to the rise in temporary differences, Tables 3 and 4 offer insight into the deferred tax positions that managers might try to control if they foresee changes in statutory tax rates. Between 1993 and 2004, the stock of deferred tax assets related to total loss and credit carryforwards increased nearly 200 percent. While much of this increase was offset through increases in Valuation Allowances, the rise in loss- and credit carryforward-related deferred tax positions still suggests in the event of a pre- 
announced decline in the corporate tax rate, there would be strong incentives to accelerate the recognition of income, and thereby to utilize carryforwards before the statutory tax rate declines.

Table 4 separates deferred tax assets from deferred tax liabilities for sub-categories that include substantial assets as well as liabilities. Some categories, such as Revenue-Related, appear relatively small in Table 3 when the net deferred tax positions are presented, but represent a significant deferred tax asset for some firms and a significant deferred tax liability for others. For example, a firm that receives cash but has not yet provided the service may have to pay income tax on that cash but does not record revenue until the associated goods or services are delivered, and so will record an unearned revenue liability and a corresponding deferred tax asset. A firm with installment sales, for which it recognizes a gain for book purposes when the sale closes but recognizes the gain for tax purposes as the payments are received, will have a deferred tax liability. Disaggregating into the asset and liability positions for certain categories also allows us to see the effect of changes to book or tax calculation of these items.

SAB 101, published in late 1999, tightened guidelines regarding how companies can recognize revenue; SAB 104, published in late 2003, further curtailed aggressive financial recognition of revenue. Evidence in Table 4 is consistent with both of these pronouncementsthe upward trend in the DTL for Revenue-Related slows beginning in 1999 and even reverses beginning in $2002 .{ }^{20}$ Table 4 presents additional detailed information that may be helpful in understanding the contribution of temporary differences to the increase in the book-tax income gap.

[insert Table 4 around here]

\footnotetext{
${ }^{20}$ An alternative explanation for the observed trend in Revenue-Related deferred tax positions that we cannot rule out is the slowing economy in the later years of our sample.
} 
The foregoing tables suggest that temporary differences are a significant portion of the book-tax income gap and provide evidence on the components of these temporary differences. We now explore the size of deferred tax positions relative to assets. This normalization is helpful for judging the importance of DTAs and DTLs relative to the book value of the firm. Table 5 reports the distribution of net DTAs and DTLs as a share of firm assets for each super-firm and for each individual firm. The net deferred tax balance is substantial for many firms. In 2002, for example, 35 percent of both super-firms and individual firms reported a net deferred tax position in excess of five percent of assets. Although the table does not show it, almost ten percent of both individual firms and super-firms had a net deferred tax position exceeding ten percent of assets. For super-firms, the maximum (minimum) net deferred tax position as a function of assets occurred in 2004 (1995) and was 14.5 percent (-31.9 percent). Overall, Table 5 suggests that while the majority of firms have a small deferred tax position relative to total assets, a nontrivial number have a more significant position.

\section{[insert Table 5 around here]}

Table 6 presents information similar to that in Table 5, but it distinguishes financial and non-financial firms. We have not separated these two groups in our earlier tables because we did not find a significant difference between them in the average (unscaled) size of the deferred balance positions or in the percent of the book-tax gap attributable to temporary differences. However, in Table 6, we separate financial and non-financial firms; their balance sheets appear to be affected differently by deferred tax positions.

\section{[insert Table 6 around here]}

Financial firms have relatively smaller deferred tax positions than non-financial firms, largely because their base of financial assets is so large. In every sample year, more than three- 
quarters of the financial firms in our sample have a net deferred tax position, either positive or negative, that represents less than three percent of total assets. About half of non-financial firms, in contrast, have deferred tax positions in this range. The extreme values of the ratio of deferred tax positions to firm assets are also smaller for financial than for non-financial firms. The maximum (minimum) net deferred tax position relative to assets for a financial firm occurred in 1994 (1997) and was 16.2 percent (-18.5 percent) while the maximum (minimum) net deferred tax position relative to assets for a non-financial firm occurred in 2001 (1995) and was 48.0 percent (-46.3 percent). For financial firms, the net deferred tax positions as a percentage of assets are distributed more tightly around zero than are the comparable positions for nonfinancial firms.

\section{TEMPORARY DIFFERENCES AND FIRM BEHAVIOR}

The presence of deferred tax positions on a corporation's balance sheet may affect several aspects of firm performance and create a range of incentives for firm behavior. We now describe several consequences of the presence of temporary differences. To focus attention on a concrete policy setting, we consider a situation in which the statutory corporate rate is expected to decline.

\section{A. Income Re-Timing Incentives}

All firms face incentives to alter the timing of reported income in the periods immediately surrounding a tax rate cut. Absent deferred tax considerations, firms will increase the present value of their after-tax income by shifting income from the period prior to the rate cut into the future in order to pay tax on that income at the lower future rate. ${ }^{21}$ The presence of

\footnotetext{
${ }^{21}$ Guenther (1994) discusses nontax costs that limit this type of tax rate arbitrage, including the cost of reporting lower financial income for debt covenants and management compensation. We acknowledge these constraints but do not measure them. Our estimates of the percent of firms who are likely to shift for NOL CF purposes may be
} 
deferred tax liabilities should exacerbate this incentive-firms will also want to delay the reversal of deferred tax liabilities so the liability is settled at a lower rate than currently recorded. Firms with deferred tax assets, however, will want to receive the deferred benefits at the higher tax rate and so have an incentive to accelerate income to the period before the tax rate reduction.

Many firms hold deferred tax positions related to NOL carryforwards - they have carried the NOL as far back as is allowed and some NOL remains to offset taxable profits in future periods. In 2004, 37 percent of the individual firms in our sample had a beginning-of-year, NOL carryforward-related DTA that would likely be affected by a federal rate cut. ${ }^{22}$ While firms with deferred tax assets related to NOL carryforwards have a strong incentive to create income in the final higher-tax-rate period in order to receive the benefit of the NOL carryforward at the higher rate, some firms with a net NOL carryforward may be unable to shift income. We assume that firms reporting taxable income have more scope to accelerate income than do firms currently in a tax loss position. In 2004, three of the firms with a net NOL carryforward are estimated to be in a tax loss positions, leaving 26 of the 78 firms with both a beginning-of-year net NOL Carryforward and positive estimated taxable income. This calculation suggests that nearly one third of our sample would have an incentive to accelerate income, as well as some capacity to do this. We are unable to extend this analysis to estimate the dollars of income these firms are likely to shift. However, Maydew's (1997) finding that the average firm in his sample shifts $\$ 11.2$ million of income, or 1.5 percent of Net Sales, in response to a 12 percent decrease in the corporate income tax rate suggests that the re-timing of corporate income associated with a change in statutory tax rates could be large enough to warrant revenue estimators considering

considered an upper bound for the percentage of firms who are likely to undertake income shifting into the higher tax regime.

${ }_{22}$ This calculation excludes disclosed state and foreign NOL carryforwards as well as carryforwards disclosed together with a tax credit (i.e., Credit and Loss Carryforwards.) The latter exclusion may cause us to understate the percentage of firms with a federal NOL carryforward. 
such rate-motivated income shifting in their estimates of the short-run revenue effects of a change in the statutory corporate tax rate.

\section{B. Preference for Tax Rate Change}

Temporary differences generally do not affect book income, while they do affect cash flow. Both when they arise and when they reverse, temporary differences affect the allocation between current and deferred tax expense and therefore affect cash paid for taxes in the current period. In most cases, the effect when the difference is recorded and when it reverses are equal and opposite. For example, when taxable depreciation exceeds book depreciation, cash outflow for taxes decreases, increasing cash flow relative to a situation in which book and taxable depreciation are equal. When this temporary difference reverses, book depreciation exceeds taxable depreciation and cash outflow for taxes increases. Both when the temporary difference arises and when it reverses, the temporary difference does not affect book income but does shift cash flow.

However, when tax rates change, the firm must revalue its deferred tax asset or liability, which in turn affects book income. Neubig (2006) and Mills (2006) argue that firms are very sensitive to the impact of tax reform on their reported earnings and recognize the potential income effect through revaluation of DTAs and DTLs. Managers who will report lower earnings as a result of these revaluations may be particularly concerned that analysts may inadvertently

assume that these one-time effects are persistent-a concern supported by Chen and Schoderbek's (2000) study of deferred tax revaluations around the 1993 tax rate change.

We illustrate the potential Net Income impact of deferred tax position revaluations with a counterfactual example in which the federal corporate income tax rate drops by five percentage 
points in $2004 .{ }^{23}$ Using the data in Tables 1 and 2, we estimate the revaluation of beginning-ofyear deferred tax positions. We do not allow for any income shifting associated with the rate change, since we do not have a shifting elasticity to apply in this setting. We limit the sample to just those firms that report federal income tax separately. This limited sample includes 80.8 percent of our firm-year observations, representing 81.8 percent of sample adjusted net deferred tax positions. The revaluation calculations exclude deferred tax positions related to tax credits, including foreign tax credits. Because credits directly offset tax liability, rather than taxable income, a rate change will not affect their valuation.

Our results are presented in Table 7. A lower tax rate reduces federal tax expense on current period income and increases the period's Net Income; we refer to this as its "direct effect." This is a persistent and long-lived effect of the rate reduction. If the 2004 corporate tax rate had been reduced to 30 percent, the direct effect would have reduced federal tax expense by $\$ 147$ million for the average super-firm. The average super-firm's Net Income in 2004 was $\$ 3,625$ million, so this reduction in tax expense represents an increase in Net Income of 4.1 percent.

\section{[insert Table 7 around here]}

In the year of the rate change, Net Income reflects both the direct effect and the revaluation effect. While we might expect the deferred tax revaluation to be second-order, for many firms it is considerably larger than the direct effect of the tax rate change. Our estimates in Table 7 suggest that for the average super-firm, the revaluation of 2003 deferred tax positions

\footnotetext{
${ }^{23}$ While many other changes in the business environment, including changes in Generally Accepted Accounting Principles, also affect deferred tax positions, we consider a statutory rate change because it is broadly applicable and its impact is relatively easy to estimate.
} 
would have increased 2004 Net Income by $\$ 328$ million, or 9.0 percent. ${ }^{24}$ Our average superfirm would have experienced a 13.1 percent increase in Net Income - two-thirds of which would have been attributable to the revaluation effect. This effect, not surprisingly, differs across firms. For firms with net DTAs, the write-down of net DTA decreases Net Income, offsetting the positive Net Income effect of the reduction in the current period's tax expense. For net DTL firms, on the other hand, the revaluation reduces the value of a balance sheet liability, which increases their Net Income. Net DTA super-firms in our sample would on average experience a $\$ 315$ million revaluation decrease in net DTA and Net Income..$^{25}$ The lower tax rate would have decreased these firms' current tax expense and increased their Net Income by $\$ 103$ million. On net, these firms would report a $\$ 212$ million earnings decrease due to the rate change, a 7.7 percent decrease in their average Net Income of \$2,755 million. Firms in our sample with a net DTL would experience, on average, a $\$ 677$ million dollar revaluation decrease in their net DTL, and a matching Net Income increase. ${ }^{26}$ They would also report $\$ 171$ million less in taxes on income generated in the current period. DTL firms average $\$ 4,097$ million of Net Income in 2004. For net DTL firms the revaluation effect reinforces the direct tax expense effect. Net Income rises, on average, by 20.7 percent for our sample firms with a net DTL.

Although our estimates of DTAs and DTLs provide some guidance on the effects of statutory rate changes, there are several reasons for caution in evaluating our estimates. First, our assumption that all DTAs and DTLs relate to federal temporary differences may lead to some overstatement of the effect of U.S. federal income tax rate changes. Second, not all DTAs and DTLs are affected by statutory rate changes. Tax credit carry-forwards, for example, are not,

\footnotetext{
${ }^{24}$ In results that are not reported here, we found that the median revaluation effect in 2004 would have increased net income by 2.1 percent - still substantial, but considerably lower than the mean effect of 9.0 percent.

${ }^{25}$ The median revaluation effect in 2004 for Net DTA firms would have decreased net income by 4.2 percent.

${ }^{26}$ The median revaluation effect in 2004 for Net DTL firms would have increased net income by 6.3 percent.
} 
because they are applied after the tax rate. We address this concern by removing credits from base deferred tax positions where possible when we estimate the revaluation effect of a tax rate change. We make the conservative assumption that any disclosure which includes credits, such as "Net Operating Loss and Credit Carry-forwards," is comprised entirely of credits.

\section{Deferred Taxes and Corporate Tax Reform}

A change in the corporate tax rate would affect firms through many channels. Our analysis highlights one aspect of corporate tax reform that is often overlooked: changes statutory rates will affect firms by requiring revaluation of their deferred tax assets and liabilities. This "temporary differences" channel will have divergent effects on firms with net deferred tax assets and those with net deferred tax liabilities, and it may lead their respective managers to have different reactions to tax reform and to pursue different strategies to shift income from the old to the new regime. Anecdotal and other evidence suggests that managers are sensitive to the impact of tax reform on reported earnings. Our findings suggest that for some firms, the effects of some corporate tax reforms on the value of deferred tax assets and liabilities can be substantial. Managers at firms with significant net deferred tax assets may lobby against statutory corporate tax rate cuts if they are primarily concerned with the short-term effect of such policy changes on reported after-tax income.

The political history of tax policy changes is replete with examples of corporate groups with closely-aligned incentives affecting policy design. In the introduction, we cited Hanna's (2010) description of the corporate tax reform debate of 2004. Pressure from firms with accumulated net operating losses was one factor in Congress' decision to enact a "qualified production activities" deduction rather than a reduction in corporate tax rates. For firms with large net deferred tax assets positions, a rate cut would have generated substantial tax expense. 
Less than two months after the passage of the American Jobs Creation Act of 2004, the Financial Accounting Standards Board (FASB) published its interpretation of the qualified production activities deduction as a special deduction, rather than a tax rate reduction, under SFAS 109. While firms with deferred tax liabilities would have preferred FASB treat the new qualified production activities deduction as a tax rate reduction, FASB's treatment is additional evidence that firms are concerned about the financial statement impact of tax rate changes.

In a different context, Neubig (2006) notes that one concern some firms may have about expanding investment incentives by adopting expensing for tax purposes is that expensing creates deferred tax liabilities that could be subject to revaluation if the corporate tax rate changes in the future - an event that some managers may seek to avoid.

Ohio's recent corporate tax reform further illustrates how firms with substantial deferred tax positions may affect the tax legislative process. The reform legislation included three distinct forms of transition relief for firms that would lose deferred tax assets when the corporate income tax was replaced by a gross receipts tax. First, firms operating in Ohio under the income tax regime were encouraged to schedule the reversal of their temporary differences during the phaseout of the corporate income tax. To the extent that any temporary items would not reverse by the end of the phase-out, an adjustment for the estimated deferred tax position at the end of the transition period was recognized in income in the period in which the phase-out began. Second, certain deferred tax assets, primarily research and development tax credits, were retained as credits under the new activity tax regime. Alvarez \& Marsal Holdings (2008) explain that these credits are not recorded as assets on the financial books of the firm, however, because SFAS 109 applies only to taxes on income. Finally, there was special transition tax relief aimed at those firms with large NOL carryforwards, which would lose the ability to use these assets under the 
new tax regime. These policies provide transition relief to firms that were 'owed' tax relief under the income tax regime and that lost this prospective tax relief as a result of the tax reform.

\section{CONCLUSIONS AND FUTURE DIRECTIONS}

This paper explores the role of temporary differences in contributing to the disparity between reported pretax book and estimated tax earnings for large U.S. corporations. Temporary differences comprise a substantial fraction of the book-tax income gap. Temporary differences that increase the book-tax income gap are larger than those that decrease it in our data sample. More than half of the firms in our sample have a net deferred tax liability, which reflects the accumulation of past excesses of book income over taxable income. Additionally, the average net deferred tax liability position is greater than the average net deferred tax asset position.

Firms exhibit substantial heterogeneity in their deferred tax positions. In 2004, more than forty percent of the firms in our sample of FORTUNE 50 companies reported a net deferred tax position valued at more than five percent of corporate assets. The observed heterogeneity suggests that firms may be affected in different ways by tax and accounting reforms. We estimate that roughly one third of the firms in our sample have strong incentives to shift income forward to maximize their use of NOL Carryforwards in response to a pre-announced reduction in the statutory corporate tax rate, while a large part of the sample likely has the opposite income shifting incentives. This heterogeneity also affects the impact of a statutory rate cut on Net Income. If the corporate tax rate had been reduced by five percentage points in 2004 , then the average firm in our sample would have experienced a \$328 million increase in Net Income due to the revaluation of its deferred tax positions. The average revaluation effect for a firm with a net deferred tax asset position is a $\$ 315$ million decrease in Net Income while the average revaluation effect for a firm with a net deferred tax liability position is a $\$ 677$ million increase. 
Understanding the disparate incentives created by deferred tax asset and liability positions is important for crafting transitional relief associated with changes in the structure of the corporate income tax.

The prospective importance of deferred tax assets and liabilities in affecting firm behavior and firm incentives is possibly even greater than the findings from our sample suggest. Many corporations are likely to experience growing deferred tax assets as a result of the recession that began in 2007. While the recently-extended NOL carryback period will enable some firms to draw down their deferred tax assets, the new tax provisions will not affect all firms. ${ }^{27}$ Moreover, as new financial products provide firms with potentially greater control over the timing of income recognition, the magnitude of their behavioral response to transitory tax incentives associated with deferred tax assets and liabilities may increase.

Our descriptive findings suggest a number of possibilities for future research. The detailed information on deferred tax positions that we have collected may provide a starting point for studying the interplay between financial accounting for taxes and various aspects of corporate behavior. One particularly interesting question is how managers respond to the incentives created by deferred tax assets and liabilities. Their responses might involve political action in support of, or opposition to, policies that would be beneficial to, or costly for, their firms, or might involve changes in the investment or financing policies that are designed to take advantage of opportunities, or minimize burdens, associated with deferred tax positions. It may, for example, be possible to investigate whether firms that are large contributors to the campaigns of legislators who serve on tax-writing committees are particularly sensitive to the nature of tax reform insofar as they have large deferred tax positions. Data such as that collected for the current project

\footnotetext{
${ }^{27}$ The Worker, Homeownership, and Business Assistance Act of 2009 allows five-year NOL carryback for NOLs incurred in 2008 or 2009. This is only useful for firms with a tax loss in 2008 or 2009 who paid tax in 2003, 2004 or 2005 , since tax payments in those years were not "accessible" under the prior two-year carryback rules.
} 
provides a much richer description of the potential heterogeneous effect of tax policies created by cross-firm differences than does the more aggregate data reported in machine-readable databases, and it consequently makes it possible to test more refined hypotheses about firm behavior. 


\section{ACKNOWLEDGEMENTS}

We are grateful to many research assistants at MIT and the University of North Carolina for collecting 10-K data entries, to Erin Towery for outstanding research assistance standardizing the mountains of data, to William Gentry (the editor), James Hines, Richard Larsen, Thomas Neubig, Richard Sansing, Andrew Schmidt, Jake Thomas, two anonymous referees, and especially Lillian Mills for helpful comments and discussion, and to the American Tax Policy Institute, the Bradley Foundation, and the National Science Foundation for research support. 


\section{REFERENCES}

Alvarez \& Marsal Holdings, LLC, 2008. "Trends in State Gross Receipts Taxes and Their FAS 109 Implications.” A\&M Tax Advisor Weekly 50. Alvarez \& Marsal, New York, NY.

Amir, Eli, Michael Kirschenheiter, and Kristen Willard, 1997. "The Valuation of Deferred Taxes." Contemporary Accounting Research 14(4): 597-622.

Bauman, Christine. C., Mark P. Bauman, and Robert F. Halsey, 2001. "Do Firms Use the Deferred Tax Asset Valuation Allowance to Manage Earnings?" Journal of American Taxation Association 23(S-1): 27-48.

Chen, Kevin C. W., and Michael P. Schoderbek, 2000. "The 1993 Tax Rate Increase and Deferred Tax Adjustments: A Test of Functional Fixation.” Journal of Accounting Research 38(1): 23-44.

Edgerton, Jesse, 2010. "Investment, Accounting, and the Salience of the Corporate Income Tax." Federal Reserve Board working paper.

Financial Accounting Standards Board, 1990. Employers' Accounting for Postretirement Benefits Other than Pensions-Statement of Financial Accounting Standards No. 106. Financial Accounting Standards Board, Norwalk, CT.

Financial Accounting Standards Board, 1992. Accounting for Income Taxes-Statement of Financial Accounting Standards No. 109. Financial Accounting Standards Board, Norwalk, CT.

Financial Accounting Standards Board, 2001. Goodwill and Other Intangible Assets-Statement of Financial Accounting Standards No. 142. Financial Accounting Standards Board, Norwalk, CT.

Financial Accounting Standards Board, 2004. "Application of FASB Statement No. 109, Accounting for Income Taxes, to the Tax Deduction on Qualified Production Activities Provided by the American Jobs Creation Act of 2004." FASB Staff Position FAS109-1. Financial Accounting Standards Board, Norwalk, CT.

Givoly, Dan, and Carla Hayn, 1992. "The Valuation of Deferred Tax Liability: Evidence from the Stock Market.” The Accounting Review 67(2): 394-410.

Guenther, David A., 1994. "Earnings Management in Response to Corporate Tax Rate Changes: Evidence from the 1986 Tax Reform Act." The Accounting Review 69(1): 230-243.

Hanna, Christopher H., 2010. "Corporate Tax Reform: Listening to Corporate America.” Journal of Corporation Law 35 (2): 283-325.

Leone, Marie, 2010. “Don’t Panic: Health-Care Hit is Minimal.” CFO.Com, March 29. 
Maydew, Edward L., 1997. "Tax-induced Earnings Management by Firms with Net Operating Losses." Journal of Accounting Research 35(1): 83-96.

Miller, Gregory S., and Douglas J. Skinner, 1998. "Determinants of the Valuation Allowance for Deferred Tax Assets Under SFAS No. 109.” The Accounting Review 73(2): 213-233.

Mills, Lillian F., 2006. "Five Things Economists and Lawyers can Learn from Accountants: An Illustration using the Domestic Production Activities Deduction." National Tax Journal 59(3): 585-597.

Neubig, Tom, 2006. "Where's the Applause? Why Most Corporations Prefer a Lower Tax Rate.” Tax Notes April 24: 483-486.

Ohio Department of Taxation, 2006. "Commercial Activity Tax Credit for Unused Franchise Tax Net Operating Losses.” Information Release 2006-06. Ohio Department of Taxation, Columbus, $\mathrm{OH}$.

Phillips, John D., Morton Pincus, Sonja O. Rego, and Huishan Wan, 2004. “Decomposing Changes in Deferred Tax Assets and Liabilities to Isolate Earnings Management Activities." Journal of the American Taxation Association 26(Supplement): 43-66.

Plesko, George A., 2004. "Corporate Tax Avoidance and the Properties of Corporate Earnings." National Tax Journal 57(3): 729-737.

Robinson, Leslie A., 2010. "Do Firms Incur Costs to Avoid Reducing Pre-Tax Earnings? Evidence from the Accounting for Low-Income Housing Tax Credits." The Accounting Review 85(2): 637-670.

Shackelford, Douglas A., Joel Slemrod, and James M. Sallee, 2009. "Financial Reporting, Tax, and Real Decisions: A Unifying Framework.” University of North Carolina working paper.

Securities and Exchange Commission, 1999. SEC Staff Accounting Bulletin: No. 101-Revenue Recognition in Financial Statements. Securities and Exchange Commission, Washington, DC.

Securities and Exchange Commission, 2003. SEC Staff Accounting Bulletin: No. 104-Revenue Recognition, Corrected Copy. Securities and Exchange Commission, Washington, DC.

Scholes, Myron S., G. Peter Wilson, and Mark A. Wolfson, 1992. "Firms' Responses to Anticipated Reductions in Tax Rates: The Tax Reform Act of 1986." Journal of Accounting Research 30(Supplement): 161-185. 


\section{APPENDIX A: SAMPLES FIRMS AND YEARS IN SAMPLE}

Our sample was constructed based on FORTUNE magazine's annual sales-based ranking of U.S. firms. The top 50 firms for each year from 1995 until 2004 were included in the sample. To mitigate the effects of changes in firm size in the net deferred tax analysis, the tax notes for all firms acquired or sold by FORTUNE 50 firms during the sample period were also included. For example, Berkshire Hathaway acquired General Re Corp in 1998, so the tax note information for General Re Corp was added to Berkshire Hathaway for years 1993-1997. Similarly, AMR Corp spun off Sabre in 2000, so going forward, tax note details for Sabre were added to AMR Corp for years 2000-2004. We use online firm histories and 10-Ks to research merger and acquisition activity. Four FORTUNE 50 firms were dropped due to insufficient disclosures: Fannie Mae, Freddie Mac, State Farm, and TIAA-CREF.

For the net deferred tax descriptive analysis, the main FORTUNE 50 firm and all of its acquired and divested components were combined into a singe aggregate firm observation, summing over the deferred tax and liability categories as well as total assets and market values.

The following 81 FORTUNE 50 "super-firms" are included in our sample: Aetna Inc, Allstate Corp., Albertsons Inc, Altria Group, American Electric Power Co., American International Group Inc, AmerisourceBergen Corp., Amoco, AMR Corp, AOL Time Warner Inc, Aquila Inc, AT\&T Corp, Bank of America Corp, BellSouth Corp, Berkshire Hathaway Inc, Cardinal Health, CenterPoint Energy Inc, Chevron Texaco Corp., Cigna Corp, Citigroup Inc, Chrysler, Coca-Cola Co, Columbia/HCA Health, ConAgra Foods Inc, ConocoPhillips, Costco Wholesale Corp., Dell Computer Corp, Dow Chemical Co, Duke Energy Co, Dynegy Inc, Eastman Kodak, El Paso Corp., Enron Corp, Exxon Mobil Corp, Ford Motor Co, General Electric Co, General Motors Corp, Goldman Sachs Group Inc., Hewlett Packard Co., Home Depot Inc., Ingram Micro Inc., Intel Corp, International Paper Co, International Business Machines, ITT Industries Inc, J C Penney Corp Inc, J P Morgan Chase \& Co, Johnson \& Johnson, Kmart Holding Corp., Kroger Co., Lockheed Martin Corp, Loews Corp., Lowe's, Marathon Oil Corp, MCI Worldcom, McKesson Corp, Merck \& Co Inc, Merrill Lynch \& Co Inc, MetLife Inc, Microsoft Corp, Morgan Stanley, Motorola Inc, PepsiCo Inc, Pfizer Inc, Procter and Gamble Co, Prudential Financial Inc, Safeway Inc, Sara Lee Corp, SBC Communications Inc, Sears Roebuck Co, Supervalu Inc, Target Corp., The Boeing Co., United Parcel Service Inc, United Technologies, Valero Energy Corp, Verizon Communications Inc, Walgreen Co, Walmart, Wells Fargo \& Co, Xerox Corp.

The following 15 FORTUNE 50 firms are included in our sample as part of another superfirm: American Stores, included with Albertsons Inc; Bank One, included with J.P. Morgan Chase \& Co; BankAmerica, included with Bank of America Corp; Bell Atlantic, included with Verizon Communications Inc; Chase Manhattan Corp, included with J.P. Morgan Chase \& Co; Citicorp, included with Citigroup Inc; Compaq Computer, included with Hewlett Packard Co.; Conoco, included with ConocoPhillips; DuPont E I De Nemours \& Co, included with ConocoPhillips; GTE, included with Verizon Communications Inc; Lucent, included with AT\&T Corp.; Medco Health, included with Merck \& Co Inc; Mobil, included with ExxonMobil Corp; Prudential Insurance, included with Prudential Financial Inc; Texaco, included with Chevron Texaco Corp. 


\section{APPENDIX B: CLASSIFICATION OF DEFERRED TAX ASSETS AND LIABILITIES}

Each deferred tax asset or liability category listed in a firm's $10-\mathrm{K}$ tax footnote is classified into one of the following aggregate categories:

- Allowances for doubtful accounts

- Employee benefits

- Other (non-pension) post-employment benefits

- Pensions

- NOL carryforwards

- Foreign tax credit carryforwards

- Other tax credits and carryforwards

- International activity-related

- Inventory

- Restructuring, merger \& acquisition

- Oil \& Gas, environmental

- Warranties

- Valuation allowances

- Expense-related

- Mark-to-market adjustments

- Intangible assets

- Leases

- Property, plant \& equipment

- Regulated accruals and deferrals

- Revenue-related

- U.S. State-related

- Subsidiary-related

Items that were too vague to categorize (e.g., 'other adjustments'), included multiple categories (e.g., 'A/R and inventory reserves') or too unusual to warrant a category (e.g., 'Bond Premiums') were classified as 'Other'. 


\section{APPENDIX C: CALCULATION EXAMPLE, THE COCA-COLA CO., 2004}

Baseline calculations, corresponding to entries in our dataset and tables:

Pretax book income $=\$ 6222$

Taxable income $=$ current tax expense $/ 0.35=\$ 1213 / 0.35=\$ 3466$

Book-tax income gap $=\$ 6222-\$ 3466=\$ 2756$

Temporary differences $=$ deferred tax expense $/ 0.35=\$ 162 / 0.35=\$ 463$

Permanent and other differences $=$ book-tax gap less temporary differences $=\$ 2756-\$ 463=\$ 2293$

While we believe the deferred tax method of calculating temporary differences suffers from fewer confounding factors than any other method, we present two alternative methods below. They, like our deferred tax method, contain noise, not bias.

\section{Alternative Method I}

One alternative method of calculating temporary differences uses the rate reconciliation to calculate permanent and other differences, and then defines temporary differences as the resulting residual. Reconciling items total $12.9 \%$ of pretax income. This translates to $\$ 803$ tax dollars of permanent and other differences (12.9\% x pretax income of \$6222) or \$2294 of permanent and other differences $(\$ 803 / 0.35)$ for Coca Cola Co. in 2004. When the firm discloses the current/deferred break down for their total tax provision (i.e. current tax expense plus deferred tax expense equals total tax provision), this alternative method results in the same figures as calculated using the first method. However, jurisdiction-specific disclosures and the tax effect of nonrecurring items often do not include current/deferred specifics. These disclosures confound this relationship and results in over- or under-stated temporary differences relative to the deferred tax expense method.

Alternative Method II

A third method of calculating temporary differences uses the change in the net deferred tax position, divided by the tax rate. For example, for Coca Cola, this would equal (\$671-\$235)/0.35. This alternative method results in a higher number than is calculated using the deferred tax expense. Text in the 10-K suggests that the discrepancy is due to a valuation allowance booked against foreign deferred tax assets. There are a number of other reasons why the change in deferred tax assets may not equal the deferred tax expense, including mergers and acquisitions, change in accounting standards and change in tax law or tax rates. As such, this method may also result in over- or understated temporary differences relative to the deferred tax method.

CONSOLIDATED STATEMENTS OF INCOME

The Coca-Cola Company and Subsidiaries

\begin{tabular}{lccc} 
Year Ended December 31, & 2004 & 2003 & 2002 \\
\hline INCOME BEFORE INCOME TAXES AND CUMULATIVE & & & \\
EFFECT OF ACCOUNTING CHANGE & & 5,495 & 5,499 \\
Income taxes & $\mathbf{1 , 2 2 2}$ & 1,148 & 1,523 \\
\hline NET INCOME BEFORE CUMULATIVE EFFECT OF & & & \\
$\begin{array}{l}\text { ACCOUNTING CHANGE } \\
\text { Cumulative effect of SFAS No. 142, net of income taxes: }\end{array}$ & $\mathbf{4 , 8 4 7}$ & 4,347 & 3,976 \\
$\quad \begin{array}{l}\text { Company operations } \\
\text { Equity investees }\end{array}$ & - & - & $\mathbf{2}$ \\
\hline
\end{tabular}


Income tax expense (benefit) consists of the following (in millions):

\begin{tabular}{|c|c|c|c|c|c|}
\hline Year Ended December 31, & & $\begin{array}{r}\text { United } \\
\text { States }\end{array}$ & $\begin{array}{r}\text { State and } \\
\text { Local }\end{array}$ & International & Total \\
\hline \multicolumn{6}{|l|}{2004} \\
\hline Current & $\$$ & 350 & $\$ 64$ & \$ 799 & $\$ 1,213$ \\
\hline Deferred & & 209 & 29 & (76) & 162 \\
\hline
\end{tabular}

A reconciliation of the statutory U.S. federal rate and effective rates is as follows:

\begin{tabular}{|c|c|c|c|}
\hline Year Ended December 31, & 2004 & 2003 & 2002 \\
\hline Statutory U.S. federal rate & $35.0 \%$ & $35.0 \%$ & 35.0 \\
\hline State income taxes-net of federal benefit & 1.0 & 0.9 & 0.9 \\
\hline $\begin{array}{l}\text { Earnings in jurisdictions taxed at rates different } \\
\text { from the statutory U.S. federal rate }\end{array}$ & $(9.4)^{1,2}$ & $(10.6)^{7}$ & $(6.0)$ \\
\hline Equity income or loss & $(3.1)^{3,4}$ & $(2.4)^{8}$ & $(2.0)^{10}$ \\
\hline Other operating charges & $(0.9)^{5}$ & $(1.1)^{9}$ & - \\
\hline Write-down/sale of certain bottling investments & - & - & $0.7^{1}$ \\
\hline Other—net & $(0.5)^{6}$ & $(0.9)$ & $(0.9)$ \\
\hline
\end{tabular}

The tax effects of temporary differences and carryforwards that give rise to deferred tax assets and liabilities consist of the following (in millions):

\begin{tabular}{|c|c|c|c|}
\hline December 31, & & 2004 & 2003 \\
\hline \multicolumn{4}{|l|}{ Deferred tax assets: } \\
\hline Property, plant and equipment & $\$$ & $71 \$$ & 87 \\
\hline Trademarks and other intangible assets & & 65 & 68 \\
\hline Equity method investments (including translation adjustment) & & 530 & 485 \\
\hline Other liabilities & & 149 & 242 \\
\hline Benefit plans & & 594 & 669 \\
\hline Net operating/capital loss carryforwards & & 856 & 711 \\
\hline Other & & 257 & 195 \\
\hline $\begin{array}{l}\text { Gross deferred tax assets } \\
\text { Valuation allowance }\end{array}$ & & $\begin{array}{r}2,522 \\
(854)\end{array}$ & $\begin{array}{c}2,457 \\
(630)\end{array}$ \\
\hline Total deferred tax assets ${ }^{1}$ & $\$$ & $1,668 \$$ & 1,827 \\
\hline \multicolumn{4}{|l|}{ Deferred tax liabilities: } \\
\hline Property, plant and equipment & $\$$ & (684) $\$$ & $(737)$ \\
\hline Trademarks and other intangible assets & & (247) & (247) \\
\hline Equity method investments (including translation adjustment) & & (612) & $(468)$ \\
\hline Other liabilities & & (71) & $(55)$ \\
\hline Other & & (180) & $(211)$ \\
\hline Total deferred tax liabilities & $\$$ & $(1,794) \$$ & $(1,718)$ \\
\hline Net deferred tax assets (liabilities) & $\$$ & (126) $\$$ & 109 \\
\hline
\end{tabular}




\section{Table 1}

Book-Tax Income Gap and Share Attributable to Temporary Differences, 1993-2004

\begin{tabular}{|c|c|c|c|c|c|c|c|}
\hline Year & $\begin{array}{c}\text { Number of } \\
\text { Super-Firms }\end{array}$ & $\begin{array}{c}\text { Median Super- } \\
\text { Firm Book-Tax } \\
\text { Income Gap (\$M) }\end{array}$ & $\begin{array}{c}\text { Median Super- } \\
\text { Firm Temporary } \\
\text { Differences (\$M) }\end{array}$ & $\begin{array}{c}\text { Median Share } \\
\text { Attributable to } \\
\text { Temporary } \\
\text { Differences (\%) }\end{array}$ & $\begin{array}{c}\text { Aggregate Super- } \\
\text { Firm Book-Tax } \\
\text { Income Gap (\$M) }\end{array}$ & $\begin{array}{c}\text { Aggregate Super- } \\
\text { Firm Temporary } \\
\text { Differences (\$M) }\end{array}$ & $\begin{array}{c}\text { Aggregate Share } \\
\text { Attributable to } \\
\text { Temporary } \\
\text { Differences (\%) }\end{array}$ \\
\hline 1993 & 71 & 25.0 & $(2.5)$ & $67.08 \%$ & $(7,987.5)$ & $(14,368.0)$ & $179.9 \%$ \\
\hline 1994 & 76 & 96.3 & 72.0 & 61.34 & $29,488.4$ & $20,371.7$ & 69.08 \\
\hline 1995 & 76 & 115.9 & 47.4 & 64.10 & $31,022.9$ & $22,762.2$ & 73.37 \\
\hline 1996 & 78 & 134.6 & 155.4 & 71.36 & $41,440.6$ & $29,578.7$ & 71.38 \\
\hline 1997 & 78 & 117.5 & 136.2 & 67.69 & $33,839.3$ & $19,123.2$ & 56.51 \\
\hline 1998 & 77 & 10.8 & 10.1 & 63.17 & $9,870.7$ & $(2,534.0)$ & -25.67 \\
\hline 1999 & 77 & 251.0 & 245.7 & 93.20 & $83,660.6$ & $67,123.7$ & 80.23 \\
\hline 2000 & 78 & 219.7 & 238.9 & 80.97 & $67,715.3$ & $63,341.0$ & 93.54 \\
\hline 2001 & 78 & 180.8 & 142.0 & 82.22 & $(20,192.0)$ & $(26,220.9)$ & 129.86 \\
\hline 2002 & 78 & 302.3 & 144.1 & 71.24 & $2,246.1$ & $42,485.6$ & $1,891.52$ \\
\hline 2003 & 78 & 736.0 & 477.1 & 75.62 & $139,877.3$ & $68,004.2$ & 48.62 \\
\hline 2004 & 78 & 607.4 & 296.6 & 66.63 & $89,942.7$ & $18,694.0$ & 20.78 \\
\hline
\end{tabular}

All data are hand-collected. Sample includes firms ranked in the Fortune 50 from 1995-2004. To standardize firms across time, firms engaged in merger, acquisition, or divestiture activity with the Fortune 50 ranked firm are included with the Fortune 50 ranked firm to create a "super-firm." The Book-Tax Income gap is calculated as Pretax Book Income less Taxable Income, where Taxable Income is calculated as Current Tax Expense divided by the maximum corporate statutory rate of $35 \%$ in all periods. Temporary differences are calculated as Deferred Tax Expense divided by 35\%. Median Share Attributable to Temporary Differences is the median value of (Temporary Differences/Book-tax Income Gap) calculated at the super-firm level. Aggregate measures are computed by summing all firms' book-tax gaps and temporary differences. 
Table 2

Sample Characteristics by Year, 1993-2004

\begin{tabular}{|c|c|c|c|c|c|c|c|c|}
\hline \multirow[b]{2}{*}{ Year } & \multirow[b]{2}{*}{$\begin{array}{l}\text { Number of } \\
\text { Super-Firms }\end{array}$} & \multirow[b]{2}{*}{$\begin{array}{l}\text { Aggregate Market } \\
\text { Capitalization of } \\
\text { Super-Firms (\$B) }\end{array}$} & \multirow[b]{2}{*}{$\begin{array}{l}\text { Aggregate Total } \\
\text { Assets of Super- } \\
\text { Firms (\$B) }\end{array}$} & \multirow{2}{*}{$\begin{array}{l}\text { Cross-sectional } \\
\text { Std. Dev. of Net } \\
\text { Deferred Tax } \\
\text { Positions (\$B) }\end{array}$} & \multicolumn{2}{|c|}{ Super-Firms with Net DTA } & \multicolumn{2}{|c|}{ Super-Firms with Net DTL } \\
\hline & & & & & Number & $\begin{array}{l}\text { Aggregate } \\
\text { Value (\$B) }\end{array}$ & Number & $\begin{array}{l}\text { Aggregate } \\
\text { Value (\$B) }\end{array}$ \\
\hline 1993 & 71 & $\$ 1,718$ & $\$ 5,202$ & $\$ 3.5$ & 31 & $\$ 52.2$ & 40 & $-\$ 79.7$ \\
\hline 1994 & 76 & 1,804 & 6,328 & 3.3 & 35 & 52.7 & 41 & -81.2 \\
\hline 1995 & 76 & 2,484 & 4,918 & 3.2 & 32 & 41.5 & 44 & -83.7 \\
\hline 1996 & 78 & 3,199 & 5,719 & 3.4 & 31 & 43.8 & 47 & -97.4 \\
\hline 1997 & 78 & 4,311 & 6,768 & 3.8 & 29 & 48.2 & 49 & -110.5 \\
\hline 1998 & 77 & 5,764 & 7,295 & 4.0 & 33 & 56.9 & 44 & -108.2 \\
\hline 1999 & 77 & 6,651 & 8,305 & 5.4 & 33 & 52.0 & 44 & -148.0 \\
\hline 2000 & 78 & 6,468 & 9,340 & 6.2 & 31 & 58.3 & 47 & -166.5 \\
\hline 2001 & 78 & 5,938 & 10,229 & 6.6 & 33 & 69.1 & 45 & -181.6 \\
\hline 2002 & 78 & 4,543 & 10,625 & 7.3 & 33 & 94.1 & 45 & -186.9 \\
\hline 2003 & 78 & 5,466 & 11,757 & 7.5 & 29 & 68.4 & 49 & -226.9 \\
\hline 2004 & 78 & 5,800 & 13,302 & 7.0 & 27 & 65.4 & 51 & -226.6 \\
\hline
\end{tabular}

All data are hand-collected except as noted. Sample includes firms ranked in the Fortune 50 from 1995-2004. To standardize firms across time, firms engaged in merger, acquisition, or divestiture activity with the Fortune 50 ranked firm are included with the Fortune 50 ranked firm to create a "super-firm." Market capitalization is calculated as Common Shares Outstanding (Compustat CSHO) multiplied by Fiscal Year-End Price (Compustat PRCC_F). 
Table 3

Components of Net Deferred Tax Positions (\$M), Average per Super-Firm, 1993-2004

\begin{tabular}{|c|c|c|c|c|c|c|c|c|c|c|c|c|}
\hline & 1993 & 1994 & 1995 & 1996 & 1997 & 1998 & 1999 & 2000 & 2001 & 2002 & 2003 & 2004 \\
\hline Allowance for doubtful accounts & 206 & 193 & 206 & 226 & 239 & 264 & 250 & 212 & 283 & 287 & 255 & 244 \\
\hline \multicolumn{13}{|l|}{ Benefits } \\
\hline \multirow{3}{*}{$\begin{array}{l}\text { Employee benefits } \\
\text { Other post-employment benefits } \\
\text { Pensions }\end{array}$} & 242 & 241 & 235 & 312 & 380 & 441 & 459 & 452 & 514 & 655 & 434 & 482 \\
\hline & 519 & 522 & 526 & 481 & 432 & 365 & 348 & 328 & 335 & 395 & 377 & 318 \\
\hline & -25 & -65 & -73 & -103 & -105 & -82 & -120 & -129 & -172 & -117 & -152 & -207 \\
\hline \multirow{4}{*}{$\begin{array}{l}\text { Credits and Carryforwards } \\
\text { NOL carryforwards } \\
\text { Foreign tax credit carryforwards } \\
\text { Other tax credits \& carryforwards }\end{array}$} & & & & & & & & & & & & \\
\hline & 165 & 168 & 161 & 174 & 174 & 214 & 265 & 310 & 369 & 509 & 524 & 575 \\
\hline & 18 & 22 & 18 & 1 & 2 & 4 & 9 & 11 & 5 & 5 & 5 & 11 \\
\hline & 182 & 190 & 183 & 176 & 197 & 186 & 214 & 215 & 241 & 379 & 435 & 452 \\
\hline International activity-related & 6 & 4 & 6 & 4 & 22 & 24 & 34 & 44 & 37 & 48 & -31 & -75 \\
\hline Inventory & 15 & 16 & 18 & 9 & 13 & 15 & 12 & 17 & 8 & 5 & 2 & -5 \\
\hline Restructuring, Merger \& Acquisition & 205 & 141 & 113 & 80 & 45 & 43 & 13 & -37 & 34 & 23 & 2 & 41 \\
\hline Oil \& Gas, Environmental & 23 & 22 & 27 & 17 & 11 & 4 & 4 & -9 & 1 & 11 & 25 & 28 \\
\hline Warranties & 5 & 5 & 6 & 4 & 3 & 5 & 5 & 5 & 60 & 84 & 90 & 102 \\
\hline Other Assets/Liabilities & 454 & 451 & 463 & 456 & 489 & 548 & 556 & 628 & 398 & 517 & 413 & 545 \\
\hline Valuation allowance & -248 & -268 & -257 & -243 & -248 & -186 & -234 & -255 & -245 & -615 & -578 & -688 \\
\hline Expense-related & -40 & -55 & -55 & -48 & -36 & -39 & -65 & -75 & -97 & -129 & -169 & -197 \\
\hline Mark-to-market adjustments & -117 & -15 & -193 & -186 & -276 & -300 & -361 & -275 & -286 & -345 & -451 & -484 \\
\hline \multicolumn{13}{|l|}{ Property } \\
\hline \multirow{3}{*}{$\begin{array}{l}\text { Intangible assets } \\
\text { Leases } \\
\text { Property, plant \& equipment }\end{array}$} & -148 & -142 & -143 & -179 & -166 & -152 & -327 & -385 & -394 & -142 & -351 & -315 \\
\hline & -208 & -217 & -227 & -256 & -280 & -266 & -293 & -328 & -333 & -376 & -365 & -369 \\
\hline & $-1,479$ & $-1,448$ & $-1,416$ & $-1,450$ & $-1,500$ & $-1,468$ & $-1,584$ & $-1,600$ & $-1,707$ & $-1,989$ & $-2,057$ & $-2,148$ \\
\hline Regulated accruals and deferrals & -17 & -20 & -21 & -22 & -29 & -25 & -32 & -36 & -35 & -40 & -43 & -45 \\
\hline Revenue-related & -139 & -113 & -114 & -125 & -132 & -205 & -220 & -210 & -219 & -197 & -178 & -93 \\
\hline U.S. State-related & 5 & 2 & -2 & -4 & -9 & -17 & -20 & -10 & -6 & -3 & -1 & 1 \\
\hline Subsidiary-related Items & -13 & -9 & -17 & -14 & -23 & -41 & -161 & -260 & -237 & -153 & -219 & -240 \\
\hline Number of "Super-Firms" in Sample & 71 & 76 & 76 & 78 & 78 & 77 & 77 & 78 & 78 & 78 & 78 & 78 \\
\hline Number of Firms in Sample & 201 & 223 & 233 & 285 & 268 & 236 & 193 & 170 & 149 & 134 & 126 & 120 \\
\hline
\end{tabular}

Information on deferred tax positions are hand collected from income tax disclosures in 10-K and Annual Report filings and assigned to 23 principal categories based on frequency and monetary significance of disclosure items. Amounts presented here are annual averages per super-fir, as super-firm is defined in Table 1 and in the text. 
Table 4

Detail of Select Components of Net Deferred Tax Positions (\$M), Average per Super-Firm, 1993-2004

\begin{tabular}{|c|c|c|c|c|c|c|c|c|c|c|c|c|c|}
\hline & & 1993 & 1994 & 1995 & 1996 & 1997 & 1998 & 1999 & 2000 & 2001 & 2002 & 2003 & 2004 \\
\hline \multicolumn{14}{|l|}{ Benefits } \\
\hline \multirow{2}{*}{ Employee benefits } & DTA & 269 & 276 & 303 & 391 & 452 & 501 & 542 & 536 & 534 & 681 & 572 & 633 \\
\hline & DTL & -27 & -35 & -68 & -79 & -72 & -60 & -83 & -84 & -20 & -26 & -137 & -151 \\
\hline \multirow{2}{*}{$\begin{array}{l}\text { Other post-employment } \\
\text { benefits }\end{array}$} & DTA & 537 & 539 & 553 & 511 & 462 & 409 & 395 & 380 & 395 & 429 & 426 & 368 \\
\hline & DTL & -18 & -16 & -27 & -29 & -30 & -43 & -46 & -52 & -60 & -34 & -48 & -50 \\
\hline \multirow{2}{*}{ Pensions } & DTA & 51 & 35 & 43 & 29 & 34 & 42 & 18 & 1 & 9 & 39 & 40 & 36 \\
\hline & DTL & -76 & -99 & -115 & -133 & -139 & -123 & -138 & -130 & -181 & -156 & -192 & -243 \\
\hline \multirow{2}{*}{ Expense-related } & DTA & 5 & 6 & 9 & 24 & 28 & 36 & 32 & 53 & 54 & 44 & 48 & 48 \\
\hline & DTL & -45 & -61 & -63 & -72 & -64 & -75 & -97 & -128 & -151 & -173 & -217 & -246 \\
\hline \multirow{2}{*}{ International activity-related } & DTA & 24 & 33 & 35 & 43 & 60 & 76 & 90 & 99 & 118 & 137 & 118 & 111 \\
\hline & DTL & -18 & -29 & -29 & -39 & -39 & -52 & -56 & -55 & -80 & -89 & -150 & -186 \\
\hline \multirow{2}{*}{ Inventory-related } & DTA & 32 & 38 & 39 & 36 & 36 & 43 & 48 & 52 & 50 & 53 & 53 & 44 \\
\hline & DTL & -17 & -22 & -21 & -27 & -24 & -28 & -36 & -35 & -41 & -49 & -52 & -49 \\
\hline \multirow{2}{*}{ Mark-to-market adjustments } & DTA & 11 & 72 & 7 & 7 & 5 & 7 & 50 & 34 & 83 & 163 & 167 & 135 \\
\hline & DTL & -127 & -87 & -200 & -193 & -281 & -307 & -411 & -309 & -369 & -508 & -617 & -619 \\
\hline \multirow{2}{*}{$\begin{array}{l}\text { Restructuring, Merger \& } \\
\text { Acquisition }\end{array}$} & DTA & 210 & 143 & 118 & 86 & 62 & 59 & 27 & 28 & 58 & 49 & 28 & 73 \\
\hline & DTL & -5 & -2 & -5 & -5 & -17 & -16 & -14 & -66 & -24 & -26 & -25 & -32 \\
\hline \multirow{2}{*}{ Oil \& Gas, Environmental } & DTA & 35 & 33 & 35 & 30 & 27 & 18 & 16 & 18 & 22 & 25 & 40 & 44 \\
\hline & DTL & -13 & -11 & -8 & -13 & -16 & -15 & -12 & -27 & -20 & -14 & -15 & -16 \\
\hline \multirow{2}{*}{ Intangible assets } & DTA & 44 & 46 & 46 & 44 & 54 & 61 & 47 & 36 & 50 & 116 & 131 & 136 \\
\hline & DTL & -191 & -188 & -190 & -223 & -220 & -213 & -373 & -422 & -444 & -257 & -483 & -451 \\
\hline \multirow{2}{*}{ Regulated accruals and deferrals } & DTA & 22 & 16 & 18 & 18 & 15 & 17 & 7 & 6 & 8 & 2 & 2 & 2 \\
\hline & DTL & -39 & -36 & -39 & -39 & -44 & -42 & -39 & -43 & -43 & -42 & -44 & -47 \\
\hline \multirow{2}{*}{ Revenue-related } & DTA & 50 & 49 & 53 & 75 & 85 & 91 & 96 & 118 & 135 & 152 & 157 & 164 \\
\hline & DTL & -189 & -162 & -167 & -199 & -217 & -296 & -316 & -328 & -354 & -349 & -335 & -257 \\
\hline \multirow{2}{*}{ U.S. State-related } & DTA & 7 & 5 & 3 & 2 & 2 & 2 & 7 & 5 & 7 & 7 & 8 & 10 \\
\hline & DTL & -2 & -2 & -4 & -5 & -11 & -19 & -26 & -15 & -13 & -10 & -9 & -9 \\
\hline
\end{tabular}

Hand-collected Information on deferred tax positions are assigned to 23 categories based on frequency and monetary significance of disclosure items. Amounts presented are annual averages per super-firm. For principal components which are primarily DTA or DTL, we do not present the DTA and DTL detail here. 
Table 5

Distribution of Net Deferred Tax Positions as a Share of Firm Assets, 1993-2004

\begin{tabular}{|c|c|c|c|c|c|c|c|}
\hline \multicolumn{8}{|c|}{ Super-Firm Sample } \\
\hline \multirow[t]{2}{*}{ Year } & \multirow{2}{*}{$\begin{array}{l}\text { Sample } \\
\text { Size }\end{array}$} & \multicolumn{3}{|c|}{$\begin{array}{c}\text { Firms with } \\
\text { Net DTL/Assets in range (\%) }\end{array}$} & \multicolumn{3}{|c|}{$\begin{array}{c}\text { Firms with } \\
\text { Net DTA/Assets in range }(\%)\end{array}$} \\
\hline & & $\leq-5 \%$ & -5 to $-3 \%$ & -3 to $0 \%$ & 0 to $3 \%$ & 3 to $5 \%$ & $\geq 5 \%$ \\
\hline 1993 & 71 & 25.4 & 5.6 & 25.4 & 31.0 & 2.8 & 9.9 \\
\hline 1994 & 76 & 27.6 & 5.3 & 21.1 & 35.5 & 6.6 & 3.9 \\
\hline 1995 & 76 & 21.1 & 13.2 & 23.7 & 31.6 & 5.3 & 5.3 \\
\hline 1996 & 78 & 23.1 & 6.4 & 30.8 & 25.6 & 10.3 & 3.8 \\
\hline 1997 & 78 & 23.1 & 7.7 & 32.1 & 25.6 & 7.7 & 3.8 \\
\hline 1998 & 77 & 22.1 & 9.1 & 26.0 & 28.6 & 7.8 & 6.5 \\
\hline 1999 & 77 & 27.3 & 5.2 & 24.7 & 31.2 & 6.5 & 5.2 \\
\hline 2000 & 78 & 25.6 & 5.1 & 29.5 & 28.2 & 5.1 & 6.4 \\
\hline 2001 & 78 & 24.4 & 5.1 & 28.2 & 25.6 & 10.3 & 6.4 \\
\hline 2002 & 78 & 23.1 & 7.7 & 26.9 & 25.6 & 2.6 & 14.1 \\
\hline 2003 & 78 & 26.9 & 3.8 & 32.1 & 21.8 & 6.4 & 9.0 \\
\hline 2004 & 78 & 25.6 & 9.0 & 30.8 & 19.2 & 7.7 & 7.7 \\
\hline \multicolumn{8}{|c|}{ Individual Firm Sample } \\
\hline \multirow[t]{2}{*}{ Year } & \multirow{2}{*}{$\begin{array}{l}\text { Sample } \\
\text { Size }\end{array}$} & \multicolumn{3}{|c|}{$\begin{array}{c}\text { Firms with } \\
\text { Net DTL/Assets in range }(\%)\end{array}$} & \multicolumn{3}{|c|}{$\begin{array}{c}\text { Firms with } \\
\text { Net DTA/Assets in range }(\%)\end{array}$} \\
\hline & & $\leq-5$ & -5 to $-3 \%$ & -3 to $0 \%$ & 0 to $3 \%$ & 3 to $5 \%$ & $\geq 5 \%$ \\
\hline 1993 & 201 & 21.9 & 6.5 & 21.4 & 38.8 & 4.0 & 7.5 \\
\hline 1994 & 223 & 20.6 & 6.7 & 22.9 & 34.5 & 9.9 & 5.4 \\
\hline 1995 & 233 & 17.2 & 8.6 & 27.0 & 32.6 & 7.3 & 7.3 \\
\hline 1996 & 285 & 17.5 & 7.4 & 25.3 & 34.7 & 6.7 & 8.4 \\
\hline 1997 & 268 & 16.8 & 7.1 & 20.1 & 36.9 & 9.0 & 10.1 \\
\hline 1998 & 236 & 16.9 & 7.2 & 19.5 & 36.0 & 9.3 & 11.0 \\
\hline 1999 & 193 & 20.2 & 5.7 & 18.7 & 38.3 & 7.3 & 9.8 \\
\hline 2000 & 170 & 18.8 & 7.1 & 21.8 & 35.3 & 8.8 & 8.2 \\
\hline 2001 & 149 & 18.8 & 5.4 & 22.8 & 32.9 & 7.4 & 12.8 \\
\hline 2002 & 134 & 17.9 & 6.0 & 26.1 & 29.1 & 3.0 & 17.9 \\
\hline 2003 & 126 & 22.2 & 6.3 & 27.0 & 23.0 & 10.3 & 11.1 \\
\hline 2004 & 120 & 21.7 & 9.2 & 28.3 & 23.3 & 6.7 & 10.8 \\
\hline
\end{tabular}

All data are hand-collected. The distribution in the upper panel is calculated at the super-firm level; the distribution in the lower panel is calculated with each individual firm as its own observation. 
Table 6

Distribution of Net Deferred Tax Positions as a Share of Firm Assets: Financial and NonFinancial Firms, 1993-2004

\begin{tabular}{|c|c|c|c|c|c|c|c|}
\hline \multicolumn{8}{|c|}{ Financial Firms } \\
\hline \multirow[t]{2}{*}{ Year } & \multirow{2}{*}{$\begin{array}{l}\text { Sample } \\
\text { Size }\end{array}$} & \multicolumn{3}{|c|}{$\begin{array}{c}\text { Firms with } \\
\text { Net DTL/Assets in range (\%) }\end{array}$} & \multicolumn{3}{|c|}{$\begin{array}{c}\text { Firms with } \\
\text { Net DTA/Assets in range (\%) }\end{array}$} \\
\hline & & $\leq-5 \%$ & -5 to $-3 \%$ & -3 to $0 \%$ & 0 to $3 \%$ & 3 to $5 \%$ & $\geq 5 \%$ \\
\hline 1993 & 34 & 2.9 & 0.0 & 23.5 & 70.6 & 0.0 & 2.9 \\
\hline 1994 & 34 & 2.9 & 0.0 & 29.4 & 50.0 & 11.8 & 5.9 \\
\hline 1995 & 32 & 3.1 & 3.1 & 40.6 & 43.8 & 0.0 & 9.4 \\
\hline 1996 & 36 & 5.6 & 2.8 & 44.4 & 36.1 & 2.8 & 8.3 \\
\hline 1997 & 35 & 2.9 & 2.9 & 51.4 & 37.1 & 0.0 & 5.7 \\
\hline 1998 & 33 & 6.1 & 3.0 & 48.5 & 36.4 & 3.0 & 3.0 \\
\hline 1999 & 28 & 3.6 & 3.6 & 35.7 & 53.6 & 3.6 & 0.0 \\
\hline 2000 & 24 & 8.3 & 4.2 & 37.5 & 50.0 & 0.0 & 0.0 \\
\hline 2001 & 24 & 0.0 & 8.3 & 41.7 & 37.5 & 8.3 & 4.2 \\
\hline 2002 & 23 & 4.3 & 4.3 & 43.5 & 43.5 & 4.3 & 0.0 \\
\hline 2003 & 21 & 0.0 & 0.0 & 47.6 & 47.6 & 4.8 & 0.0 \\
\hline 2004 & 18 & 0.0 & 0.0 & 50.0 & 50.0 & 0.0 & 0.0 \\
\hline \multicolumn{8}{|c|}{ Non-Financial Firms } \\
\hline \multirow[t]{2}{*}{ Year } & \multirow{2}{*}{$\begin{array}{l}\text { Sample } \\
\text { Size }\end{array}$} & \multicolumn{3}{|c|}{$\begin{array}{c}\text { Firms with } \\
\text { Net DTL/Assets in range (\%) }\end{array}$} & \multicolumn{3}{|c|}{$\begin{array}{c}\text { Firms with } \\
\text { Net DTA/Assets in range }(\%)\end{array}$} \\
\hline & & $\leq-5 \%$ & -5 to $-3 \%$ & -3 to $0 \%$ & 0 to $3 \%$ & 3 to $5 \%$ & $\geq 5 \%$ \\
\hline 1993 & 167 & 25.7 & 7.8 & 21.0 & 32.3 & 4.8 & 8.4 \\
\hline 1994 & 189 & 23.8 & 7.9 & 21.7 & 31.7 & 9.5 & 5.3 \\
\hline 1995 & 201 & 19.4 & 9.5 & 24.9 & 30.8 & 8.5 & 7.0 \\
\hline 1996 & 249 & 19.3 & 8.0 & 22.5 & 34.5 & 7.2 & 8.4 \\
\hline 1997 & 233 & 18.9 & 7.7 & 15.5 & 36.9 & 10.3 & 10.7 \\
\hline 1998 & 203 & 18.7 & 7.9 & 14.8 & 36.0 & 10.3 & 12.3 \\
\hline 1999 & 165 & 23.0 & 6.1 & 15.8 & 35.8 & 7.9 & 11.5 \\
\hline 2000 & 146 & 20.5 & 7.5 & 19.2 & 32.9 & 10.3 & 9.6 \\
\hline 2001 & 125 & 22.4 & 4.8 & 19.2 & 32.0 & 7.2 & 14.4 \\
\hline 2002 & 111 & 20.7 & 6.3 & 22.5 & 26.1 & 2.7 & 21.6 \\
\hline 2003 & 105 & 26.7 & 7.6 & 22.9 & 18.1 & 11.4 & 13.3 \\
\hline 2004 & 102 & 25.5 & 10.8 & 24.5 & 18.6 & 7.8 & 12.7 \\
\hline
\end{tabular}

All data are hand-collected except as noted. The distributions are calculated with each individual firm as its own observation. The sample parallels that of the individual firm analysis in the lower panel of Table 5. Industry is determined using SIC codes obtained from Compustat; financial firms are SIC codes 6000-6799. 
Table 7

Mean Impact of Federal Statutory Rate Decrease to 30\% (\$M), 1993-2004 Panel A: All Super-Firms

\begin{tabular}{|c|c|c|c|c|c|c|c|c|}
\hline & $\begin{array}{c}\text { Number } \\
\text { of } \\
\text { Super- } \\
\text { Firms }\end{array}$ & $\begin{array}{c}\text { Mean } \\
\text { Pretax } \\
\text { Income }\end{array}$ & $\begin{array}{c}\text { Mean } \\
\text { Net } \\
\text { Income }\end{array}$ & $\begin{array}{c}\text { Beginning } \\
\text { of Period } \\
\text { Adjusted } \\
\text { Net DTA }\end{array}$ & $\begin{array}{c}\text { Revaluation } \\
\text { Effect on } \\
\text { Net Income }\end{array}$ & $\begin{array}{c}\text { Current } \\
\text { Period } \\
\text { Federal } \\
\text { Tax Exp }\end{array}$ & $\begin{array}{c}\text { Direct } \\
\text { Effect } \\
\text { on Net } \\
\text { Income }\end{array}$ & $\begin{array}{c}\text { Total } \\
\text { Effect } \\
\text { on Net } \\
\text { Income }\end{array}$ \\
\hline 1994 & 66 & 2,606 & 4,841 & -486 & 69 & 569 & 81 & 150 \\
\hline 1995 & 69 & 2,902 & 1,629 & -463 & 66 & 615 & 88 & 154 \\
\hline 1996 & 69 & 3,542 & 2,243 & -516 & 74 & 763 & 109 & 183 \\
\hline 1997 & 72 & 3,615 & 2,530 & -574 & 82 & 767 & 110 & 192 \\
\hline 1998 & 69 & 3,484 & 2,884 & -690 & 99 & 789 & 113 & 212 \\
\hline 1999 & 69 & 4,575 & 3,012 & -580 & 83 & 1,121 & 160 & 243 \\
\hline 2000 & 69 & 5,152 & 2,142 & $-1,241$ & 177 & 1,219 & 174 & 351 \\
\hline 2001 & 71 & 3,049 & 1,933 & $-1,466$ & 209 & 578 & 83 & 292 \\
\hline 2002 & 72 & 2,785 & 140 & $-1,615$ & 231 & 759 & 108 & 339 \\
\hline 2003 & 73 & 4,520 & 3,100 & $-1,438$ & 205 & 876 & 125 & 330 \\
\hline 2004 & 74 & 5,302 & 3,625 & $-2,298$ & 328 & 1,029 & 147 & 475 \\
\hline
\end{tabular}

Panel B: Super-Firms with Beginning of Period Net DTA

\begin{tabular}{|c|c|c|c|c|c|c|c|c|}
\hline 1994 & 29 & 3,079 & 7,234 & 1,514 & -216 & 656 & 94 & -122 \\
\hline 1995 & 31 & 3,820 & 2,448 & 1,414 & -202 & 778 & 111 & -91 \\
\hline 1996 & 29 & 3,625 & 2,337 & 1,152 & -165 & 683 & 98 & -67 \\
\hline 1997 & 30 & 3,859 & 2,552 & 1,280 & -183 & 658 & 94 & -89 \\
\hline 1998 & 28 & 3,145 & 2,677 & 1,569 & -224 & 589 & 84 & -140 \\
\hline 1999 & 32 & 4,089 & 2,645 & 1,590 & -227 & 881 & 126 & -101 \\
\hline 2000 & 31 & 4,501 & 2,920 & 1,430 & -204 & 952 & 136 & -68 \\
\hline 2001 & 26 & 3,749 & 2,459 & 1,857 & -265 & 608 & 87 & -178 \\
\hline 2002 & 32 & 2,994 & 1,808 & 1,720 & -246 & 537 & 77 & -169 \\
\hline 2003 & 28 & 3,623 & 2,493 & 2,865 & -409 & 629 & 90 & -319 \\
\hline 2004 & 26 & 4,065 & 2,755 & 2,203 & -315 & 721 & 103 & -212 \\
\hline
\end{tabular}

Panel C: Super-Firms with Beginning of Period Net DTL

\begin{tabular}{|l|c|c|c|c|c|c|c|c|}
\hline 1994 & 37 & 2,219 & 2,965 & $-2,054$ & 293 & 501 & 72 & 365 \\
\hline 1995 & 38 & 2,145 & 960 & $-1,995$ & 285 & 482 & 69 & 354 \\
\hline 1996 & 40 & 3,471 & 2,174 & $-1,724$ & 246 & 820 & 117 & 363 \\
\hline 1997 & 43 & 3,428 & 2,514 & $-1,898$ & 271 & 849 & 121 & 392 \\
\hline 1998 & 41 & 3,690 & 3,025 & $-2,232$ & 319 & 922 & 132 & 451 \\
\hline 1999 & 37 & 4,971 & 3,329 & $-2,457$ & 351 & 1,329 & 190 & 541 \\
\hline 2000 & 38 & 5,570 & 3,526 & $-3,421$ & 489 & 1,437 & 205 & 694 \\
\hline 2001 & 45 & 2,644 & 1,629 & $-3,387$ & 484 & 560 & 80 & 564 \\
\hline 2002 & 40 & 2,618 & $-1,194$ & $-4,283$ & 612 & 937 & 134 & 746 \\
\hline 2003 & 45 & 5,079 & 3,478 & $-4,116$ & 588 & 1,029 & 147 & 735 \\
\hline 2004 & 48 & 5,973 & 4,097 & $-4,737$ & 677 & 1,195 & 171 & 848 \\
\hline
\end{tabular}

All data are hand-collected. The sample is limited to firms who separately report Federal Tax Expense. We adjust Beginning of Period Net DTA for Credits, as discussed in Section V. All effects are calculated assuming a 30\% Federal Statutory Rate, rather than the actual rate of $35 \%$. 